\title{
Phosphoinositide 3-Kinase P1108-Signaling Is Critical for Microbiota-Activated IL-10 Production by B Cells that Regulate Intestinal Inflammation
}

\author{
Akihiko Oka ${ }^{1,2,+}$ (D) Yoshiyuki Mishima ${ }^{1,2,+} \oplus$, Bo Liu ${ }^{1}$, Jeremy W. Herzog ${ }^{1}$, \\ Erin C. Steinbach ${ }^{1,3}$, Taku Kobayashi ${ }^{4,5}$, Scott E. Plevy 1,4,6 and R. Balfour Sartor 1,4,* \\ 1 Center for Gastrointestinal Biology and Disease, Department of Medicine, Division of Gastroenterology and \\ Hepatology, University of North Carolina at Chapel Hill, Chapel Hill, NC 27599, USA; \\ akihiko_oka@med.unc.edu (A.O.); mtmtyui@med.shimane-u.ac.jp (Y.M.); bo_liu@med.unc.edu (B.L.); \\ jeremy_herzog@med.unc.edu (J.W.H.); erin_klein@med.unc.edu (E.C.S.); scott.plevy@synlogictx.com (S.E.P.) \\ 2 Department of Internal Medicine II, Shimane University Faculty of Medicine, Izumo, \\ Shimane 693-8501, Japan \\ 3 Division of Allergy, Immunology and Rheumatology, Department of Pediatrics, University of North \\ Carolina School of Medicine, Chapel Hill, NC 27599, USA \\ 4 Department of Microbiology and Immunology, University of North Carolina at Chapel Hill, \\ Chapel Hill, NC 27599, USA; kobataku@insti.kitasato-u.ac.jp \\ 5 Center for Advanced IBD Research and Treatment, Kitasato University Kitasato Institute Hospital, \\ Minato-ku, Tokyo 108-8642, Japan \\ 6 Synlogic Therapeutics, Boston, MA 02139, USA \\ * Correspondence: rbs@med.unc.edu; Tel.: +1-919-966-0149 \\ + These authors contributed equally to this work.
}

Received: 30 August 2019; Accepted: 20 September 2019; Published: 21 September 2019

\begin{abstract}
The phosphoinositide 3-kinase catalytic subunit p1108 (PI3K $\delta$ ) gene maps to a human inflammatory bowel diseases (IBD) susceptibility locus, and genetic deletion of PI3K $\delta$ signaling causes spontaneous colitis in mice. However, little is known regarding the role of PI3K $\delta$ on IL-10-producing B cells that help regulate mucosal inflammation in IBD. We investigated the role of PI3K $\delta$ signaling in B cell production of IL-10, following stimulation by resident bacteria and $\mathrm{B}$ cell regulatory function against colitis. In vitro, B cells from $\mathrm{PI} 3 \mathrm{~K} \delta \mathrm{D} 910 \mathrm{~A} / \mathrm{D} 910 \mathrm{~A}$ mice or wild-type B cells treated with PI3K specific inhibitors secreted significantly less IL-10 with greater IL-12p40 following bacterial stimulation. These B cells failed to suppress inflammatory cytokines by co-cultured microbiota-activated macrophages or $\mathrm{CD} 4^{+} \mathrm{T}$ cells. In vivo, co-transferred wild-type $\mathrm{B}$ cells ameliorated T cell-mediated colitis, while PI3K $\delta^{\mathrm{D} 910 \mathrm{~A} / \mathrm{D} 910 \mathrm{~A}} \mathrm{~B}$ cells did not confer protection from mucosal inflammation. These results indicate that PI3K $\delta$-signaling mediates regulatory $\mathrm{B}$ cell immune differentiation when stimulated with resident microbiota or their components, and is critical for induction and regulatory function of IL-10-producing B cells in intestinal homeostasis and inflammation.
\end{abstract}

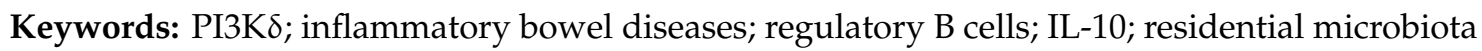

\section{Introduction}

Inflammatory bowel diseases (IBD), represented by Crohn's disease and ulcerative colitis, are chronic intestinal immune disorders characterized by dysregulated immune response to enteric resident bacteria in genetically susceptible hosts [1-3]. Resident bacteria induce pro-inflammatory cytokines such as IL-12p40 and TNF- $\alpha$ from host cells, which are the main therapeutic targets of most 
current IBD therapies $[1,3,4]$. However, the same microorganisms can also induce anti-inflammatory responses in normal hosts $[1-3,5,6]$. A delicate, homeostatic balance between anti-inflammatory and pro-inflammatory cytokines is maintained in healthy individuals, while dysregulated immune balances against resident bacteria are a key factor in the pathogenesis of IBD [1-3,5,7].

The anti-inflammatory cytokine IL-10 is secreted by many types of intestinal cells, including $\mathrm{T}$ cells, B cells, macrophages, dendritic cells and epithelial cells [4,8-11]. Previous studies have mainly focused on T cells and macrophages to determine the roles of IL-10 in the pathogenesis of IBD [1,3,4,12], while our work and that of others has demonstrated the importance of IL-10 production by B cells in experimental colitis [10,11,13-17]. Depletion of B cells contributes to the development of human IBD $[15,16]$ and enhanced inflammation in a murine model of chronic colitis [14]. We have also shown that IL-10-producing B cells induced by enteric bacteria maintain mucosal homeostasis and protect against colonic inflammation [6,11]. Those observations indicate that intestinal B cells play a protective role through IL-10 production to maintain mucosal homeostasis. However, the detailed mechanisms underlying induction, function and maintenance of bacteria-activated IL-10-producing B cells are not fully understood.

Microarray analysis comparing IL-10-producing with non-producing splenic B cells has revealed that phosphoinositide-3 kinases (PI3Ks)-Akt signaling is a key pathway of IL-10 production [18]. Activation of PI3Ks signaling in B cells suppressed allergic diseases through IL-10 production [18]. PI3Ks are recognized as a critical regulator of cell growth and immune function [19]. Class IA PI3Ks, which are heterodimeric enzymes consisting of a catalytic subunit $(\mathrm{p} 110 \alpha, \mathrm{p} 110 \beta$ or $\mathrm{p} 110 \delta)$ and a regulatory subunit (p85, p55 or p50), regulate toll-like receptor (TLR) signaling in both positive and negative ways [12,20-25] in Myd88-dependent and independent manners [26]. The PI3K subunit p1108 (PI3K $\delta$ ) is highly expressed in leukocytes, whereas $\mathrm{p} 110 \alpha$ and $\mathrm{p} 110 \beta$ are expressed ubiquitously [27]. Colonic PI3K $\delta$ is induced immediately after TLR activation by enteric bacteria $[12,23,24]$. Together, these data suggest PI $3 \mathrm{~K} \delta$ is a gate-keeper to control immune responses to enteric bacteria and is an early event in TLR signaling [23].

As for PI3K $\delta$ in gastrointestinal diseases, the human PI3K $\delta$ gene (encoded by PIK3CD) maps to the IBD7 susceptibility locus $[28,29]$ and a loss of PI3K $\delta$ leads to defective B cell function and intestinal inflammation in humans [30]. Similarly, a loss-of-function mutation of PI3K $\delta$ gene induces spontaneous colitis through Th1/Th17 activation in mice [12,31,32]. Although the mechanisms by which PI3K $\delta$ dysfunction induces colitis remain unclear, reduced IL-10 production by bacteria-stimulated macrophages and regulatory $\mathrm{T}$ cells potentially contribute to induce colitis in PI3K $\delta$ mutant mice $[12,32,33]$. Conversely, B cells are a major source of resident bacteria-stimulated IL-10 production in the colon, and IL-10-producing B cells play a pivotal role in maintaining mucosal homeostasis [6,11], while the involvement of PI3K $\delta$-signaling in B cell IL-10-production is not fully understood. Thus, we hypothesized that PI3K $\delta$-signaling impacts bacteria-stimulated IL-10 producing B cells and regulates intestinal inflammation. Macrophages and effector $\mathrm{CD} 4^{+} \mathrm{T}$ cells play a critical role in intestinal inflammation $[1,3,4]$. To explore this hypothesis, we examined cytokine profiles of in vitro co-cultured macrophages or $\mathrm{CD} 4^{+} \mathrm{T}$ cells with PI3K $\delta$-mutant $\mathrm{B}$ cells. In addition, we investigated

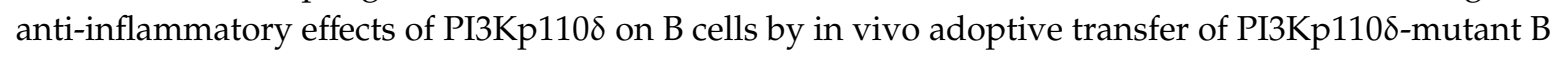
cell into a T cell-mediated colitis model.

\section{Materials and Methods}

\subsection{Mice}

C57BL/6J background wild-type (WT), IL-10-deficient $\left(I l 10^{-/-}\right)$and Rag2-deficient (Rag2 $\left.{ }^{-/-}\right)$mice were obtained from Jackson laboratory (Bar Harbor, ME, USA). We generated $\mathrm{Il10}^{-/-} ; \mathrm{Rag}^{-/-}$double-deficient

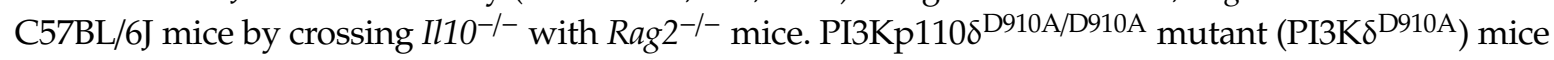
on the C57BL/6J background, which have a loss-of-function (catalytically inactive) point mutation in a gene encoding the PI3K catalytic subunit p1108, were previously obtained from Dr. B. Vanhaesebroeck 
(Queen Mary University of London, London, UK) [31]. Il10-eGFP-reporter (WT; Il10 ${ }^{\mathrm{eGFP}}$ ) mice on the C57BL/6J background, which exhibit normal IL-10 secretion ability, were provided by Dr. C. L. Karp (Global Health, Bill and Melinda Gates Foundation, Seattle, WA, USA) [34]. Il10-eGFP-reporter; PI3K $\delta^{\mathrm{D} 910 \mathrm{~A}}$ mice (PI3K $\delta^{\mathrm{D} 910 \mathrm{~A}}$; Il10 ${ }^{\mathrm{eGFP}}$ ) on a C57BL/6J background were generated by crossing PI3K $\delta^{\mathrm{D} 910 \mathrm{~A}}$ with $\mathrm{WT}$; $1110^{\mathrm{eGFP}}$ mice. All mice were bred and housed in specific-pathogen-free (SPF) conditions at the University of North Carolina at Chapel Hill (UNC). Age and numbers of used mice are indicated in figures or legends. All animal procedures were approved by the UNC Institutional Animal Care and Use Committee. Genotyping of deficient/mutant/transgenic mice were performed by PCR using the following oligonucleotides: Il10 5', 5'-ACCAAGGTGTCTACAAGGCCATGAATGAATT-3'; GFP 5', 5'-GAGGAAATTGCATCGCATTGTCTG AGTAGGT-3'; Il10 3', 5'-CAAAGGCAGACAAACAATACACCATTCCCA-3', PI3K $\delta$ common, 5' - CCT GCACAGAAATGCACTTCC-3'; PI3K $\delta$ wild-type reverse, 5'-AACGAAGCTCTCAGAGAAAGC TGG-3'; PI3K $\delta^{\text {D910A }}$ mutant reverse, 5'-CGCCTTCTATCGCCTTCTTGAC-3'. Rag2 common, 5'-CAGCGCT CCTCCTGATACTC-3'; Rag2 wild-type reverse, 5'-TGCATTCCTAGAGCGTCCTT-3'; Rag2 mutant reverse, 5'-GGTCATCCTTTGCAACACAG-3', Il10 common, 5'-CTTGCACTACCAAAGCCACA-3'; Il10 wild-type reverse, 5'-GTTATTGTCTTCCCGGCTGT-3'; Il10 mutant reverse, 5'-CCACACGCGTCACCTTAATA-3'.

\subsection{Cecal Bacterial Lysate (CBL)}

As an in vitro physiological bacterial stimulator, cecal bacterial lysate (CBL) was prepared from cecal contents from SPF C57BL/6J WT mice as described previously [35,36]. In brief, cecal contents were disrupted with 0.1-mm glass microbeads (BioSpec Products, Bartlesville, OK, USA) in MD solution containing $0.1 \mathrm{M}$ magnesium chloride (Sigma-Aldrich, St. Louis, MO, USA) and $0.1 \mathrm{mg} / \mathrm{mL}$ DNase I (Worthington Biochemical, Lakewood, NJ, USA) by using a bead beater (Bio-Rad Laboratories, Hercules, CA, USA) and were centrifuged at $10,000 \mathrm{rpm}$ for $15 \mathrm{~min}$ at $4{ }^{\circ} \mathrm{C}$. The supernatants were filtrated through $0.45-\mu \mathrm{m}$ filters (Genesee Scientific, San Diego, CA, USA). Sterility of the lysates was verified by YCFA [37] agar cultures at $37^{\circ} \mathrm{C}$ for 5 days aerobically and anaerobically (Whitley MG500 workstation, $\mathrm{N}_{2}: \mathrm{H}_{2}: \mathrm{CO}_{2}=80: 10: 10$, Don Whitley Scientific, West Yorkshire, UK). Protein concentrations were measured by Bradford method with Bio-Rad protein assay kit (Bio-Rad Laboratories).

\subsection{Cell Isolation from Spleen, $M L N$ and $c L P$}

Spleens and mesenteric lymph nodes (MLNs) were mechanically dissociated in complete medium RPMI1640 (Gibco/Life Technologies, Carlsbad, CA, USA) containing 5\% heat-inactivated fetal bovine serum (FBS) (Millipore-Sigma, Burlington, MA, USA), $100 \mathrm{U} / \mathrm{mL}$ penicillin-streptomycin (Gibco/Life Technologies), $55 \mu \mathrm{M}$ 2-mercaptoethanol (Sigma-Aldrich) and $1 \mathrm{mM}$ sodium pyruvate (Gibco/Life Technologies). Red blood cells (RBCs) in spleen samples were lysed with red blood cell lysing buffer (Sigma-Aldrich). Cell preparations were filtrated through 70- $\mu$ m nylon mesh (Fisher Scientific, Pittsburgh, PA, USA) to achieve single-cell suspensions. For separation of colonic lamina propria (cLP) cells, colons were opened longitudinally and washed with cold PBS (Mediatech, Manassas, VA, USA) to remove luminal content and mucus. After washing, colons were cut into 1-cm pieces and incubated in Hanks' balanced salt solution (HBSS) (Mediatech) containing 4 mM EDTA (Mediatech), $10 \mathrm{mM}$ dithiothreitol (Sigma-Aldrich), 2.5\% FBS and $100 \mathrm{U} / \mathrm{mL}$ penicillin-streptomycin for $20 \mathrm{~min}$ at $37^{\circ} \mathrm{C}$ with stirrer for $250 \mathrm{rpm}$ to remove mucus and epithelial cells. After washing, the denuded tissues were digested with HBSS containing $0.5 \mathrm{mg} / \mathrm{ml}$ collagenase type IV (Sigma-Aldrich), $2.5 \%$ FBS and $100 \mathrm{U} / \mathrm{mL}$ penicillin-streptomycin for $30 \mathrm{~min}$ at $37^{\circ} \mathrm{C}$ with stirrer for $350 \mathrm{rpm}$. After digesting tissues, the cLP cell suspensions were filtered through 100- $\mu$ m nylon mesh (Fisher Scientific) and purified using a $40-70 \%$ discontinuous percoll gradient (20 min, room temperature, GE Healthcare, Piscataway, NJ, USA). Obtained cLP cells were washed with cold HBSS to remove percoll. Viability of isolated spleen, MLN, cLP cells was shown to be greater than $90 \%$ viable by trypan blue dye exclusion. 


\subsection{Cell Purification of APCs, BMDMs, B Cells and Naïve T Cells}

Antigen-presenting cells (APCs) were separated from spleens from $\mathrm{IllO}^{-/-} ; \mathrm{Rag}^{-\mathrm{I}^{-}}$ double-deficient mice as described previously [36]. In brief, after RBC-lysis, spleen cells were overnight pulsed with $10 \mu \mathrm{g} / \mathrm{mL}$ CBL from C57BL/6J WT mice in complete medium at $37^{\circ} \mathrm{C}$ with $5 \% \mathrm{CO}_{2}$. After pulsing, APCs were collected and washed twice with PBS to remove soluble bacterial components and cytokines. Bone marrow-derived macrophages (BMDMs) were obtained as previously described [32]. B cells were purified magnetically by positive selection with anti-CD19 microbeads (Miltenyi Biotec, San Diego, CA, USA) after negative selection by a mixture of anti-CD90.2, anti-CD11c and anti-Ter119 microbeads (Miltenyi Biotec) according to the manufacturer's instructions. Final B cell fractions were confirmed to be greater than $99.5 \%$ pure by flow cytometry, while cell viability was shown to be greater than $95 \%$ by trypan blue dye exclusion. Naïve CD4 ${ }^{+} \mathrm{T}$ cells $\left(\mathrm{CD} 44^{\text {neg }} \mathrm{CD} 62 \mathrm{~L}^{+} \mathrm{CD} 4^{+}\right.$ $\mathrm{T}$ cells) were magnetically purified by naïve $\mathrm{CD} 4^{+} \mathrm{T}$ cells isolation kit (negative separation with anti-CD8a, CD11b, CD11c, CD19, CD25, B220, CD49b, CD105, MHC class II, Ter-119, TCR- $\gamma / \delta$, and CD44 microbeads, Miltenyi Biotec). Purity of naïve $\mathrm{CD} 4^{+} \mathrm{T}$ cells was confirmed to be greater than $94.7 \%$ by flow cytometry using anti-CD3, TCR- $\beta$, CD4, CD8, CD44, and CD62L antibodies, while cell viability was shown to be greater than $95 \%$ by trypan blue dye exclusion.

\subsection{Cell Culture with Bacterial Products and PI3K-Related Inhibitors}

$1 \times 10^{6}$ unfractionated cells from spleen, MLN or cLP and colonic B cells were cultured in complete medium in 96-well round-bottom plates (Costar, Washington DC, MA, USA) for $24 \mathrm{~h}$ with or without the following bacterial products and PI3K-related inhibitors: $10 \mu \mathrm{g} / \mathrm{mL} \mathrm{CBL;} 100 \mathrm{ng} / \mathrm{mL}$ Pam3CSK4 (Pam, InvivoGen, San Diego, CA, USA); 200 ng/mL lipopolysaccharide (LPS, InvivoGen); 500 nM CpG-DNA (CpG, InvivoGen); $2 \mu \mathrm{m}$ PI3K $\delta$-selective inhibitor IC87114 (Selleck chemicals, Houston, TX, USA); $2 \mu \mathrm{m}$ PI3K-global inhibitor LY294002 (Selleck chemicals) and $0.5 \mu \mathrm{m}$ Wortmannin (Sigma-Aldrich); $0.5 \mu \mathrm{m}$ Akt inhibitor API-2 (Bio-Techne, Minneapolis, MN, USA); dimethyl sulfoxide (DMSO, Fisher Scientific) as a vehicle. The doses of the above stimulants and inhibitors were chosen based on previous findings $[6,11,32,36]$ and dose-related toxicity test cultures (cell viability of wild-type splenocytes after 1-day culture with a range of doses $0.1,0.5,1,2,5,10,20 \mu \mathrm{M}$ of individual inhibitors). We chose the highest effective, but nontoxic doses of each inhibitor that resulted in a range of $75-82 \%$ cell viability, which were similar to $78 \%$ cell viability of the DMSO control group. Following cell cultures, supernatants were collected for measurements of cytokines by ELISA, while cells were analyzed by flow cytometry.

\subsection{B Cell Co-Culture Assays with CD4 ${ }^{+} T$ Cells and Macrophages}

$2 \times 10^{5}$ naïve $\mathrm{CD}^{+} \mathrm{T}$ cells plus $2 \times 10^{5}$ APCs were cultured with $5 \times 10^{5}$ B cells in 96-well plates for $24 \mathrm{~h}$. In another experiment, $1 \times 10^{5} \mathrm{~J} 774$ A.1 macrophage cell line (TIB-67, passage 10-15, ATCC, Gaithersburg, MD, USA) or BMDMs were cultured with $5 \times 10^{5}$ B cells, or LPS or CpG-stimulated B cell supernatants in 48-well plates for $72 \mathrm{~h}$. These cells were selectively stimulated with either $10 \mu \mathrm{g} / \mathrm{mL}$ CBL, $100 \mathrm{ng} / \mathrm{mL}$ Pam, $200 \mathrm{ng} / \mathrm{mL}$ LPS or $500 \mathrm{nM} \mathrm{CpG}$ in complete medium. Following cell cultures, supernatants were collected for measurements of cytokines by ELISA.

\subsection{T cell Proliferation Assay}

Splenic naïve CD4 ${ }^{+} \mathrm{T}$ cells isolated from C57BL/6J WT mice were labeled with CFSE (BD Biosciences, San Jose, CA, USA) according to the manufacturer's instructions. The $5 \times 10^{5}$ CFSE-labeled naïve $\mathrm{CD}^{+} \mathrm{T}$ cells were co-cultured with or without $1 \times 10^{6}$ splenic B cells isolated from WT or PI3K $\delta^{\mathrm{D} 910 \mathrm{~A}}$ mice with stimulation by $10 \mu \mathrm{g} / \mathrm{mL}$ anti-CD3e monoclonal antibody, $2 \mu \mathrm{g} / \mathrm{mL}$ anti-CD28 monoclonal antibody (Table S1) and $10 \mu \mathrm{g} / \mathrm{mL}$ CBL for $72 \mathrm{~h}$. PI3K $\delta$-selective inhibitor IC-87114 was selectively added. The proportion of $\mathrm{CD}^{+} \mathrm{CFSE}^{+}$cells was analyzed by flow cytometry. 


\subsection{Adoptive Transfer of Naïve CD $4^{+} T$ Cells and $C D 19^{+}$B Cells}

Recipient $\mathrm{IlOO}^{-/-}$; $\mathrm{Rag}^{-/-}$double-deficient mice were injected intraperitoneally with $5 \times 10^{5}$ splenic naïve $\mathrm{CD} 4^{+} \mathrm{T}$ cells isolated from WT mice along with or without $1 \times 10^{6}$ splenic $\mathrm{B}$ cells from WT, $\mathrm{PI} 3 \mathrm{~K} \delta^{\mathrm{D} 910 \mathrm{~A}}$ or $1 l 10^{-/-}$donors. Six weeks after cell transfer, mice were sacrificed and colitis severity was evaluated by fecal lipocalin-2, histology scoring, and gene expression of proinflammatory cytokines in tissues.

\subsection{Preparation for Quantification of Fecal Lipocalin-2}

Fecal samples (10-20 mg) were incubated overnight at $4{ }^{\circ} \mathrm{C}$ in PBS containing $0.1 \%$ Tween 20 (Fisher Scientific) and vortexed shortly to obtain homogenous fecal suspensions. The fecal suspensions were centrifuged for $10 \mathrm{~min}$ at $12,000 \mathrm{rpm}$ at $4{ }^{\circ} \mathrm{C}$. Clear supernatants were collected and stored at $-20^{\circ} \mathrm{C}$.

\subsection{ELISA}

Lipocalin-2 (Lcn) levels in fecal supernatant and cytokine levels in cell cultures were determined by ELISAs in duplicate, according to the manufacturer's protocols (Lcn, IL-10, IL-17a, IFN- $\gamma$, TNF- $\alpha$ and IL-12p40 non-allele specific: R\&D Systems, Minneapolis, MN, USA).

\subsection{Quantitative PCR}

The tissue RNA extractions were performed with RNeasy Plus Mini kit (Qiagen, Germantown, MD, USA) according to the manufacturer's protocols. cDNA was created with the SensiFAST cDNA synthesis kit (Bioline, Memphis, TN, USA) by PCR $\left(25^{\circ} \mathrm{C}, 10 \mathrm{~min} ; 42{ }^{\circ} \mathrm{C}, 15 \mathrm{~min} ; 85^{\circ} \mathrm{C}, 5 \mathrm{~min}\right)$. Quantitative PCR were performed with QuantStudio3 (Thermo Fisher Scientific, Pittsburgh, PA, USA) using SYBR No-ROX reagents (Bioline) with the following PCR setting: $95^{\circ} \mathrm{C}, 2 \mathrm{~min} ; 95^{\circ} \mathrm{C}, 5 \mathrm{~s}$; 40 cycles of $\left(60^{\circ} \mathrm{C}, 10 \mathrm{~s} ; 72{ }^{\circ} \mathrm{C}, 20 \mathrm{~s}\right)$; melting curve analysis: $95{ }^{\circ} \mathrm{C}, 15 \mathrm{~s} ; 60^{\circ} \mathrm{C}, 15 \mathrm{~s} ; 95^{\circ} \mathrm{C}, 15 \mathrm{~s}$. The data were created by comparative $\mathrm{Ct}$ method $\left(2^{-\Delta \Delta \mathrm{Ct}}\right)$. The following PCR primers were used: Il12b (5'-CGCAAGAAAGAAAAGATGAAGGAG-3') and (5'-TTGCATTGGACTTCGGTAGATG-3'); Ifng (5'-CTTCCTCATGGCTGTTTCTGG-3') and (5'-ACGCTTATGTTGTTGCTGATGG-3'); Il17a (5'-CTCAGACTACCTCAACCGTTC-3') and (5'-TGAGCTTCCCAGATCACAGAG-3'); Tnfa (5'-ACC CTCACACTCAGATCATCTTCTC-3') and (5'-TGAGATCCATGCCGTTGG-3'); Actb (5'-AGCC ATGTACGTAGCCATCCAG-3') and (5'-TGGCGTGAGGGAGAGCATAG-3'). Each cDNA sample was analyzed in duplicate for quantitative assessment of RNA amplification. Melting curve analysis confirmed the presence of single products with expected melting temperatures.

\subsection{Flow Cytometry}

For flow cytometric analysis, single cells were incubated with anti-CD16/CD32 (BD Biosciences) as a Fc block for $10 \mathrm{~min}$ at $4{ }^{\circ} \mathrm{C}$ and then stained with fluorochrome-conjugated antibodies and proper isotype controls (Table S1) for $20 \mathrm{~min}$ at $4{ }^{\circ} \mathrm{C}$. Cells were washed and resuspended in PBS containing $1 \%$ bovine serum albumin (BSA) and then analyzed on a LSRII flow cytometer with FACSDiva software version 6.0 (BD Biosciences). Singlet live $\mathrm{CD} 45^{+}$cells were analyzed by FlowJo software version 10 (FlowJo, Ashland, OR, USA) with the following gating strategy: B cell $\left(\mathrm{B} 220^{+} \mathrm{CD} 19^{+}\right), \mathrm{CD} 4^{+} \mathrm{T}$ cell $\left(\mathrm{TCR} \beta^{+} \mathrm{CD}^{+} \mathrm{CD} 4^{+} \mathrm{CD} 8^{\text {neg }}\right), \mathrm{CD} 8^{+} \mathrm{T}$ cell $\left(\mathrm{TCR} \beta^{+} \mathrm{CD} 3^{+} \mathrm{CD} 4^{\text {neg }} \mathrm{CD} 8^{+}\right)$, natural killer (NK) cell $\left(\mathrm{TCR} \beta^{\text {neg }} \mathrm{NK} 1.1^{+}\right)$, macrophage $\left(\mathrm{TCR} \beta^{\text {neg }} \mathrm{CD} 11 \mathrm{~b}^{+} \mathrm{CD} 64^{+}\right)$, Neutrophil $\left(\mathrm{TCR} \beta^{\text {neg }} \mathrm{MHCII}{ }^{\text {neg }} \mathrm{Ly}_{6 \mathrm{G}}{ }^{+}\right)$and dendritic cell (TCR $\beta^{\text {neg }} \mathrm{CD} 64^{\text {neg }} \mathrm{MHCII}{ }^{+} \mathrm{CD} 11 \mathrm{c}^{+}$). When GFP was assessed, WT cells (GFP-negative) were stained with all antibodies used in the experiment except for the FITC/GFP channel, which is equivalent to a fluorescence-minus-one control [6]. 


\subsection{Histological Colitis Score}

Intestinal tissues were removed and fixed in $10 \%$ buffered formalin. Paraffin-embedded sections $(5 \mu \mathrm{m})$ were prepared and stained with hematoxylin and eosin (H\&E) by the Histology Core of the Center for Gastrointestinal Biology and Disease at UNC. The scoring of mucosal inflammation in cecum, proximal colon and distal colon was performed in a blinded fashion, with each region being graded from 0 to 4 as described previously [35]. The total histology scores represent the summation of all the scores (maximum score of 12).

\subsection{Statistical Analysis}

Statistical analysis was performed with Prism 8 software (GraphPad, San Diego, CA, USA). Significance between two groups was determined by unpaired Mann-Whitney test, while significance between more than 3 groups was determined by analysis of variance (ANOVA), followed by Dunn's multiple comparisons test. For all statistical comparisons, $P$ values less than 0.05 were considered significant.

\section{Results}

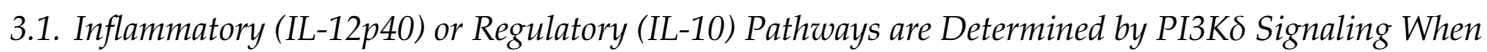 Stimulated by Resident Bacteria}

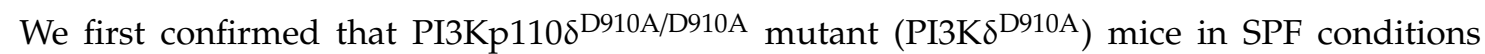
spontaneously develop colitis beginning at the age of 14 weeks or older based on serial fecal lipocalin-2 (f-Lcn) levels (Figure 1a) [38]. Histology assessment indicated that 8 week old PI3K $\delta^{\mathrm{D} 910 \mathrm{~A}}$ mice did not show any mucosal inflammation, while 18 week old PI3K $\delta^{\mathrm{D} 910 \mathrm{~A}}$ mice developed colitis characterized by mucosal crypt hyperplasia, lamina propria (LP) infiltration by neutrophils and lymphocytes and increased intraepithelial lymphocytes (Figure 1b,c) [12,31,32]. As inflammation modifies mucosal immune status [39-41], 8-10 week old mice were predominantly used for in vitro experiments. The size of MLNs and spleens are smaller and the length of colons is shorter in $8-10$ week old PI3K $\delta^{\mathrm{D} 910 \mathrm{~A}}$ mice compared to WT mice (Figure S1a). The cell numbers of PI3K $\delta^{\mathrm{D} 910 \mathrm{~A}}$ mice were decreased in the spleen, MLN and colonic LP (cLP) with striking reduction of frequencies in B cells (Figure S1b,c), which might be due to impaired cell proliferation, differentiation or survival in $\mathrm{PI} 3 \mathrm{~K} \delta^{\mathrm{D} 910 \mathrm{~A}}$ mice $[31,42]$.

Given that PI3K $\delta^{\mathrm{D} 910 \mathrm{~A}}$ mice require the presence of resident microbiota to develop chronic colitis [12,32] similar to $I l 10^{-/-}$mice [43], we next investigated immune responses against bacterial products in WT and PI3K $\delta^{\text {D910A }}$ mice in vitro. Pam (TLR 1/2), LPS (TLR 4) and CpG-DNA (TLR 9) were selected based on the previous observations that these TLR ligands efficiently activate B cells $[12,20-25,32]$. We also utilized cecal bacterial lysates (CBL) as a physiological bacterial stimulant $[35,36]$. WT MLN cells produced abundant IL-10 when stimulated with any of the bacterial ligands tested, while PI3K $\delta^{\mathrm{D} 910 \mathrm{~A}}$ MLN cells secreted substantially decreased amounts of IL-10 (Figure 1d). Conversely, bacterial product-stimulated PI3K $\delta^{\text {D910A }}$ MLN cells produced relatively high IL-12p40 levels, a subunit of pro-inflammatory cytokines IL-12 and IL-23 that promotes Th1/Th17 responses [24], although levels were not as pronounced as by $1110^{-/-}$MLN cells (Figure 1e). These results indicate that a dysregulated immune response against bacterial product stimulation may contribute to mucosal inflammation in PI3K $\delta^{\mathrm{D} 910 \mathrm{~A}}$ mice.

We next performed a pharmacologic blockade of PI3K signaling on WT cells during bacterial product stimulation. IL-10 secretion by CBL-stimulated WT CLP, MLN and spleen cells was significantly inhibited by PI3K-global inhibitors (LY294002 and Wortmannin), PI3K $\delta$-selective inhibitor (IC87114) and an inhibitor of Akt, a molecule downstream of the PI3K pathway (Figure 1f and Figure S2) [44]. However, these inhibitors had no effect on IL-12p40 secretion. The IL-10/IL-12p40 ratio, which in part reflects the regulatory activity of immune cells, was significantly reduced by the PI3K/Akt inhibitors (Figure $1 \mathrm{f}$ and Figure S2). As cell viability confirmed by the trypan blue exclusion test was not different between the groups (data not shown), the limited IL-10 production by the PI3K/Akt inhibitors was 
neither due to the cytotoxicity nor induction of apoptosis by the inhibitors. The lack of suppression of IL-12p40 further confirmed the viability of cells after inhibitor treatment. Together, PI3K-Akt signaling appears to skew the bacterial-stimulated immune phenotype toward regulatory (IL-10) rather than inflammatory (IL-12p40) responses.
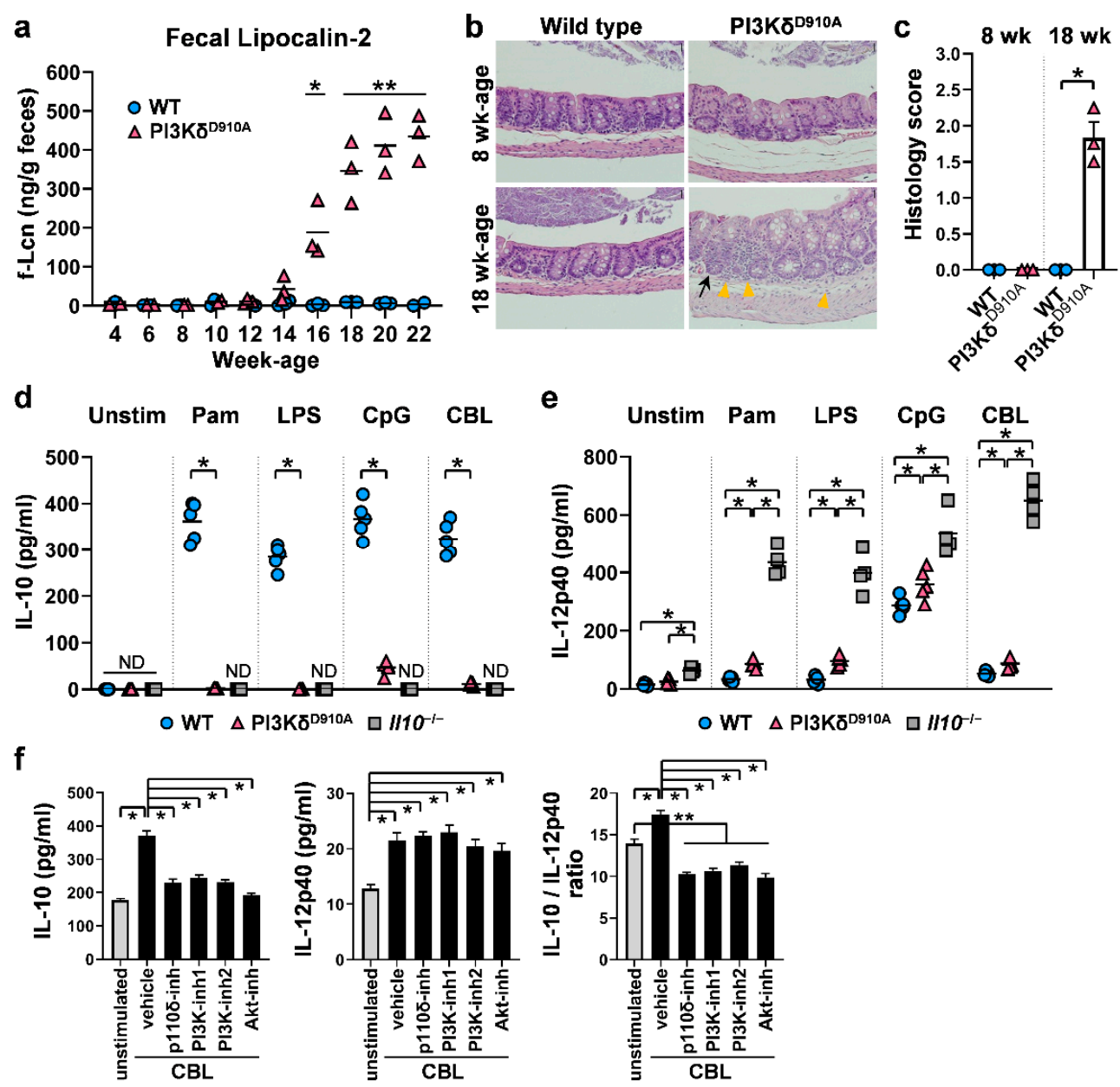

Figure 1. Inflammatory or regulatory phenotypes are determined by PI3K $\delta$ signaling. (a) The time course of concentrations of fecal lipocalin-2 (f-Lcn) from wild-type (WT) and PI3K $\delta^{\mathrm{D} 910 \mathrm{~A}}$ mice. (b) Representative images of H\&E-stained cecal samples from C57BL/6 wild-type mice (WT) or PI3Kp1108 D910A/D910A mice $\left(\mathrm{PI} 3 \mathrm{~K}^{\mathrm{D}}{ }^{\mathrm{D} 10 \mathrm{~A}}\right.$ ) at 8 and 18 weeks of age. The scale bars represent $100 \mu \mathrm{m}$. Black arrow indicates crypt hyperplasia. Yellow arrowhead indicates infiltration of neutrophils and lymphocytes. (c) Histology scores of WT or PI3K $\delta^{\mathrm{D} 910 \mathrm{~A}}$ mice at 8 and 18 weeks of age are shown. $(\mathbf{d}, \mathbf{e}) 1 \times 10^{6}$ unfractionated mesenteric lymph node (MLN) cells from WT, PI3K $\delta^{\mathrm{D} 910 \mathrm{~A}}$ or IL-10-deficient $\left(I l 10^{-/-}\right)$mice were cultured with medium alone (unstim), Pam3CSK4 (Pam, 100 ng/mL), lipopolysaccharide (LPS, 200 ng/mL), CpG-DNA (CpG, $500 \mathrm{nM}$ ) or cecal bacterial lysate (CBL, $10 \mu \mathrm{g} / \mathrm{mL})$ in complete medium for $24 \mathrm{~h}$ at $37{ }^{\circ} \mathrm{C}$ with $5 \% \mathrm{CO}_{2}$. Supernatant levels of (d) IL-10 and (e) IL-12p40 were quantified by ELISA. (f) $1 \times 10^{6}$ unfractionated cLP from WT mice were cultured with or without CBL $(10 \mu \mathrm{g} / \mathrm{ml})$ in the absence or presence of specific PI3K/AKT-related inhibitors or vehicle control in complete medium for $24 \mathrm{~h}$. IL-10 and IL-12p40 levels in cell culture supernatants were measured by ELISA and IL-10/IL-12p40 ratios were calculated. PI3K/Akt-related inhibitors: PI3Kp1108-selective inhibitor (p1108-inh, IC87114, $2 \mu \mathrm{M})$, PI3K-global inhibitors (PI3K-inh1: LY294002, $2 \mu \mathrm{M}$ and PI3K-inh2: wortmannin, $0.5 \mu \mathrm{M}$ ); Akt inhibitor (Akt-inh, API-2, $0.5 \mu \mathrm{M}$ ). Vehicle control: dimethyl sulfoxide. $\mathrm{N}=4-5 /$ group. Each symbol represents the result from individual mice and bars indicate the mean in a,d-e. Mean \pm SEM are shown in c,f. Mann-Whitney unpaired two-tailed test was used for a,c. Dunn's multiple comparisons test following one-way ANOVA was used for $\mathbf{d}-$ f. ${ }^{*} p<0.05,{ }^{* *} p<0.01$. ND indicates not detected. 


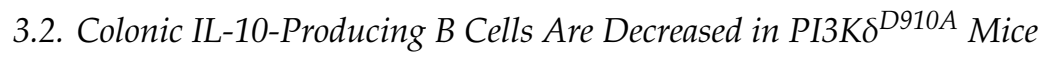

$B$ cells are one of the key protective immune cells through IL-10 secretion in the pathogenesis of IBD $[6,9-11,14,17,45-47]$ and the frequency of B cells is markedly decreased in PI3K $\delta^{\mathrm{D} 910 \mathrm{~A}}$ mice (Figure S1c). Thus we investigated how PI3K $\delta$ signaling influences the kinetics and functions of intestinal IL-10-producing regulatory B cells using IL-10-eGFP reporter mice (normal PI3K $\delta$ (WT); $I l 10^{\mathrm{eGFP}}$ and PI3K $\delta^{\mathrm{D} 910 \mathrm{~A}}$; Il10 ${ }^{\mathrm{eGFP}}$ ). Impressively, the number of cLP IL-10-producing B cells from 8-10 week old PI3K $\delta^{\text {D910A }}$; Il10 ${ }^{\text {eGFP }}$ mice, which have not yet developed colitis, were lower by 8 -fold compared with those in WT; Il10 eGFP mice (Figure 2a). This reduction was large compared with the other regulatory cells, since $\mathrm{FOXP} 3^{+} \mathrm{CD} 4^{+}$regulatory $\mathrm{T}$ cells showed relatively modest reduction in PI3K $\delta^{\text {D910A }}$ cLP (2-fold) (Figure $2 b$ ). In contrast, $16-18$ week old PI3K $\delta^{\mathrm{D} 910 \mathrm{~A}}$; $I l 10^{\mathrm{eGFP}}$ mice with inflamed colons did not show significant reduction of cLP IL-10-producing B cell numbers (Figure 2c) or mean fluorescent intensity (data not shown), likely because inflammation induces IL-10 production by B cells $[40,45]$.

In vitro, B cells were an important source of bacterial-stimulated IL-10 production (Figure 2d), and the frequencies of IL-10-producing B cells in PI3K $\delta^{\text {D910A }}$ MLN cell cultures following bacterial stimulation were significantly lower compared to those in WT cell cultures (Figure 2d,e). Of note, IL-10-producing B cells produced more IL-10 in response to bacterial stimulation than did regulatory $\mathrm{T}$ cells both in vivo (Figure $2 \mathrm{a}, \mathrm{b}$ ) and in vitro (Figure $2 \mathrm{f}$ ). To further analyze the association of the PI3K $\delta$ pathway in intestinal IL-10-producing B cells, cLP B cells from WT mice were cultured with PI3K/AKT inhibitors in the presence or absence of bacterial stimulation. CBL promoted regulatory activity in B cells, indicated by an increased IL-10/IL-12p40 ratio, while blockade of PI3K-global or PI3K $\delta$-specific pathways significantly reversed this effect by selectively inhibiting secretion of IL-10 but not IL-12p40 (Figure 2g). These observations suggest that the PI3K signaling pathway is important for the IL-10-mediated regulatory function of bacteria-induced IL-10-producing B cells. In addition, we observed relatively lower fluorescence intensity of GFP (IL-10) in PI3K $\delta^{\mathrm{D} 910 \mathrm{~A}}$; $I 110^{\mathrm{eGFP}}$ B cells compared to WT; Il10 ${ }^{\mathrm{eGFP}}$ B cells (Figure S3), indicating functionally low activity of IL-10-producing PI3K $\delta^{\mathrm{D} 910 \mathrm{~A}} \mathrm{~B}$ cells. To identify the mechanisms underlying the lower IL-10 secreting ability in $\mathrm{PI} 3 \mathrm{~K} \delta^{\mathrm{D} 910 \mathrm{~A}}$; Il10 ${ }^{\mathrm{eGFP}} \mathrm{B}$ cells, we examined the surface markers in intestinal B cells. As we demonstrated recently, the phenotype of intestinal regulatory B cells in WT mice is $\operatorname{IgM}{ }^{\text {low }} \operatorname{IgD}{ }^{\text {low }} C D 23^{\text {low }} C D 24$ high $[6]$. In contrast, gut PI3K $\delta^{\mathrm{D} 910 \mathrm{~A}}$; Il10 ${ }^{\mathrm{eGFP}} \mathrm{B}$ cells show different expression patterns characterized by higher levels of IgM, IgD, and CD23, and lower expression of CD24 compared to WT B cells (Figure S4), indicating potentially different responses to stimuli. Together, these results suggest that a reduced number and functional properties of IL-10-producing B cells may contribute to the pathogenesis of intestinal inflammation in PI3K $\delta^{\mathrm{D} 910 \mathrm{~A}}$ mice.

\subsection{Bacteria-Stimulated PI3K $\delta^{D 910 A}$ B Cells Do Not Suppress Pro-Inflammatory Cytokine Secretion by Macrophages}

Intestinal macrophages are a major source of cytokines in IBD [1,3,4]. To investigate the anti-inflammatory function of regulatory B cells on bacterial-activated macrophages, splenic B cells from either PI3K $\delta^{\mathrm{D} 910 \mathrm{~A}}$ or WT mice were co-cultured with the macrophage cell line J774, as a source of pro-inflammatory innate cytokines $[1,3,4]$ (Figure 3a). PI3K $\delta^{\mathrm{D} 910 \mathrm{~A}}$ B cells produced less IL-10 than did WT B cells when stimulated by bacteria components (Figure $3 \mathrm{~b}$ ), with further induction of IL-10 by WT, but not PI3K $\delta^{\mathrm{D} 910 \mathrm{~A}}$, B cells in co-culture with J744 macrophages. Surprisingly, macrophages alone did not secrete IL-10 in the absence of B cells. LPS-, CpG- and CBL-induced IL-12p40 and TNF- $\alpha$ production by macrophages was significantly suppressed by co-cultured WT but not PI3K $\delta^{\mathrm{D} 910 \mathrm{~A}} \mathrm{~B}$ cells (Figure 3c,d). These results indicate that IL-10-producing B cells regulate macrophage responses to enteric bacterial ligands and that PI3K $\delta$ signaling is required for B cell inhibition of macrophage activation by bacterial products. 
a

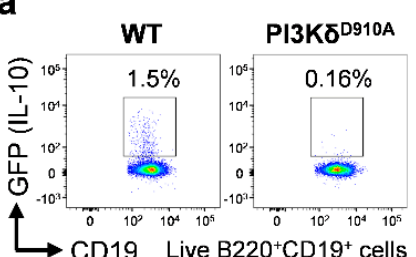

CD19 Live B220 ${ }^{+} \mathrm{CD} 19^{+}$cells

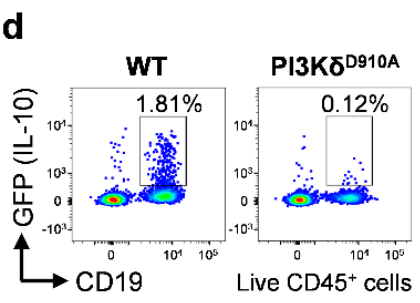

b

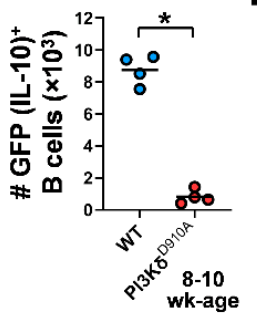

e

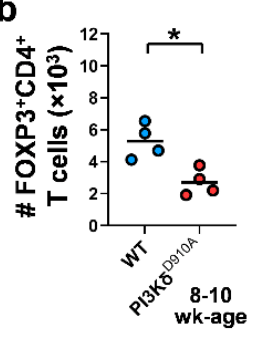

c

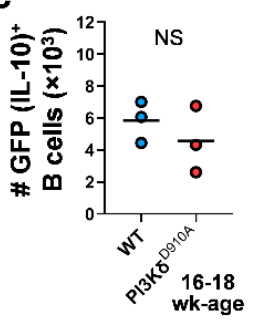

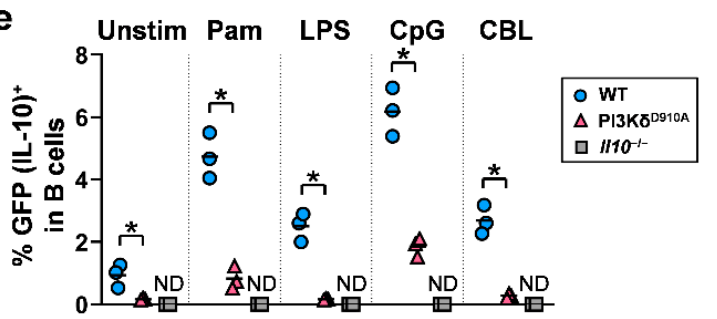

f

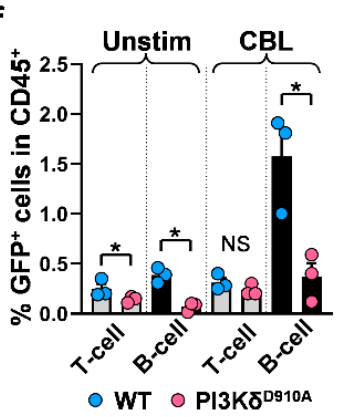

g
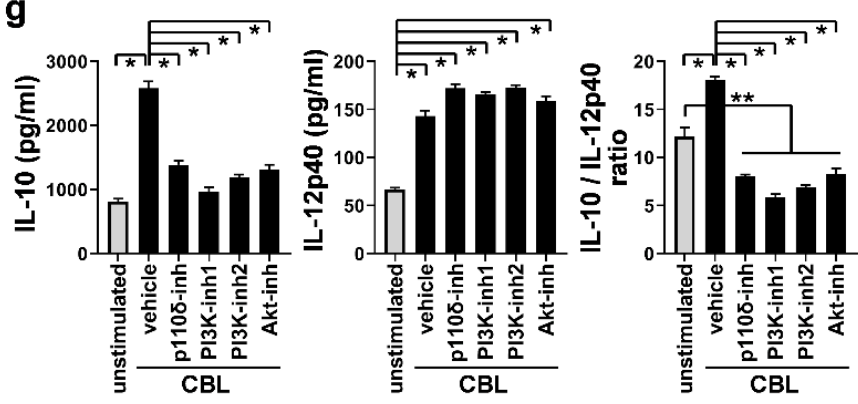

Figure 2. IL-10-producing $\mathrm{B}$ cells are significantly decreased in the colon of $\mathrm{PI} 3 \mathrm{~K} \delta^{\mathrm{D} 910 \mathrm{~A}}$ mice.

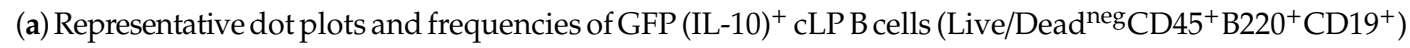
from 8-10-week-old normal PI3K $\delta(\mathrm{WT})$; Il10 ${ }^{\mathrm{eGFP}}$ mice or PI3K $\delta^{\mathrm{D} 910 \mathrm{~A}}$; Il10 ${ }^{\mathrm{eGFP}}$ mice. Cell numbers are presented per $1 \times 10^{6}$ live cLP cells (Live/Dead ${ }^{\text {neg }} \mathrm{CD} 45^{+}$). (b) The abundance of cLP FOXP3 ${ }^{+} \mathrm{CD} 4^{+}$ $\mathrm{T}$ cells (Live/Dead ${ }^{\text {neg }} \mathrm{CD} 45^{+} \mathrm{TCR} \beta^{+} \mathrm{CD}^{+} \mathrm{CD} 4^{+} \mathrm{CD}^{\text {neg }} \mathrm{FOXP3}^{+}$) is demonstrated from 8-12-week-old WT; Il10 ${ }^{\mathrm{eGFP}}, \mathrm{PI} 3 \mathrm{~K} \delta^{\mathrm{D} 910 \mathrm{~A}}$ or $I l 10^{-/-}$mice. (c) $\mathrm{GFP}^{+}$B cells from 16-18-week-old WT; Il10 ${ }^{\mathrm{eGFP}}$ or PI3K $\delta^{\mathrm{D} 910 \mathrm{~A}}$; Il10 ${ }^{\mathrm{eGFP}}$ mice are shown. $(\mathbf{d}-\mathbf{f}) 1 \times 10^{6}$ unfractionated MLN cells from 8-10-week-old WT; Il10 ${ }^{\mathrm{eGFP}}, \mathrm{PI} 3 \mathrm{~K} \delta^{\mathrm{D} 910 \mathrm{~A}}$ or $I l 10^{-/-}$mice were cultured with medium alone (unstim), Pam3CSK4 (Pam, $100 \mathrm{ng} / \mathrm{mL}$ ), lipopolysaccharide (LPS, $200 \mathrm{ng} / \mathrm{mL})$, CpG-DNA (CpG, $500 \mathrm{nM})$ or CBL $(10 \mu \mathrm{g} / \mathrm{mL})$ in complete medium for $24 \mathrm{~h}$ at $37{ }^{\circ} \mathrm{C}$ with $5 \% \mathrm{CO}_{2}$. Representative dot plots of MLN cells stimulated with CBL are shown in d. The percentages of GFP (IL-10) ${ }^{+}$in the total B cell population are shown in e. The percentages of $\mathrm{GFP}^{+} \mathrm{T}$ cells $\left(\mathrm{CD} 45^{+} \mathrm{TCR} \beta^{+} \mathrm{CD} 3^{+}\right)$and $\mathrm{B}$ cells $\left(\mathrm{CD} 45^{+} \mathrm{B} 220^{+} \mathrm{CD} 19^{+}\right)$in MLN cells $\left(\mathrm{CD} 45^{+}\right)$stimulated with CBL are shown in $\mathrm{f}$. $(\mathrm{g}) 5 \times 10^{6} \mathrm{cLP}$ B cells magnetically isolated from WT mice were cultured with or without CBL $(10 \mu \mathrm{g} / \mathrm{mL})$ in the absence or presence of PI3K/Akt inhibitors or vehicle control as described in Figure 1 legend in complete medium for 24 h. IL-10 and IL-12p40 levels in supernatants were measured by ELISA and IL-10/IL-12p40 ratios were calculated. Each symbol represents the result from individual mice, and bars indicate the mean in a-c, and e. Mean \pm SEM are shown in f,g. Mann-Whitney unpaired two-tailed test was used for a-c, e, one-tailed for $\mathrm{f}$. Dunn's multiple comparisons test following one-way ANOVA was used for $g$. ${ }^{*} p<0.05,{ }^{* *} p<0.01$. ND indicates not detected. NS indicates not significant. 
a

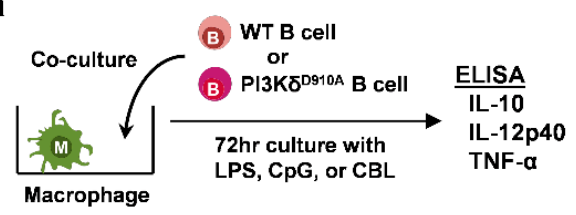

C

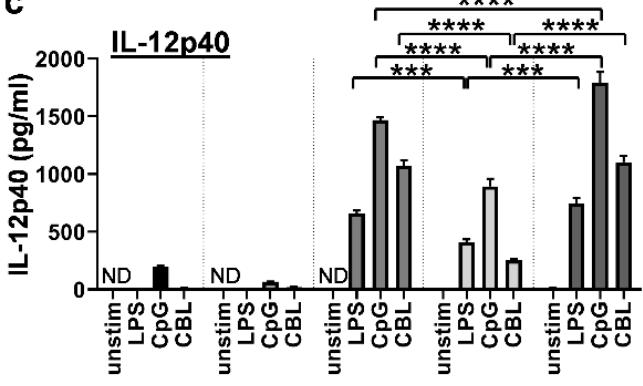

b

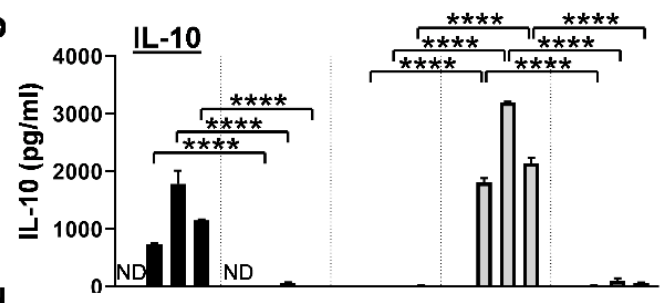

d

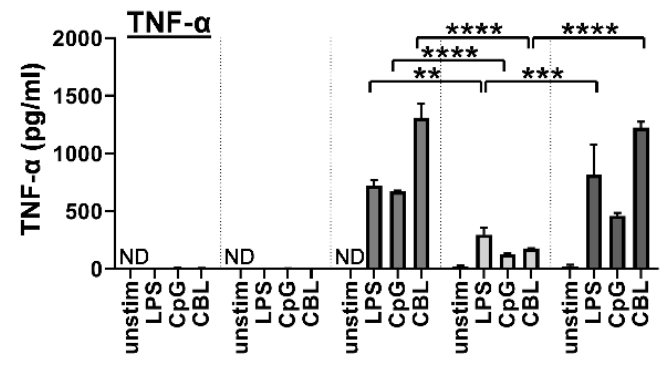

\begin{tabular}{|c|c|c|c|c|c|c|c|c|c|c|c|}
\hline B cell & WT & PI3K ${ }^{\text {D910A }}$ & - & WT & PI3Kס & B cell & WT & PI3K D9910A $^{\text {D9 }}$ & - & WT & PI3K ${ }^{\mathrm{D910A}}$ \\
\hline Macrophage & - & - & + & + & + & Macrophage & - & - & + & + & + \\
\hline
\end{tabular}

Figure 3. Bacteria-stimulated WT but not PI3K $\delta^{\mathrm{D} 910 \mathrm{~A}}$ B cells suppress IL-12p40 and TNF- $\alpha$ secretion by macrophages. (a) $1 \times 10^{5} \mathrm{~J} 774$ macrophages were cultured with $5 \times 10^{5}$ splenic B cells from C57BL/6 mice (WT) or PI3K $\delta^{\text {D910A }}$ mice with various bacterial stimuli, LPS $(200 \mathrm{ng} / \mathrm{mL}), \mathrm{CpG}(500 \mathrm{nM}), \mathrm{CBL}(10 \mu \mathrm{g} / \mathrm{mL})$ or medium alone (unstim) for $72 \mathrm{~h}$ in complete medium at $37{ }^{\circ} \mathrm{C}$ with $5 \% \mathrm{CO}_{2}$. Supernatants were assessed for (b) IL-10, (c) IL-12p40, and (d) TNF- $\alpha$ by ELISA in duplicate. Mean \pm SEM. N = 5-6/group. Dunn's multiple comparisons test following 2-way ANOVA was used. ${ }^{* *} p<0.01,{ }^{* * *} p<0.001$, $* * * * p<0.0001$. ND indicates not detected.

\subsection{Secreted IL-10 is the Dominant Way B Cells Regulate Pro-Inflammatory Cytokine Production in} Macrophages in Response to Bacterial Products

We next sought to determine the mechanisms of WT B cells' anti-inflammatory effects. Although humoral factors, especially secreted IL-10, are a key mediator of regulatory B cell activity direct cell-to-cell contact can also mediate B cells regulatory function [45,46]. Thus, we evaluated which factor is more predominantly involved in the bacteria-stimulated regulatory activity in B cells against inflammatory macrophages. To explore these possibilities, murine bone marrow-derived macrophages were cultured in the supernatants (excluding cells) from bacterial product-stimulated WT or PI3K $\delta$ D910A B cells (Figure 4a). As expected, IL-10 levels in PI3K $\delta^{\text {D910A }}$ B cell supernatants were lower than those in WT B cell supernatants (Figure 4b). Pro-inflammatory IL-12p40 and TNF- $\alpha$ produced by the macrophages were significantly decreased with the supernatants from WT B cells, but only partially suppressed by the supernatants from PI3K $\delta^{\text {D910A }}$ B cells (Figure 4c). Blockade of IL-10 signaling by anti-IL-10 receptor antibody negated the regulatory effect of the supernatant from WT B cells, indicating that the anti-inflammatory effect was primarily mediated by IL-10 (Figure 4d). These results suggest that incomplete suppression by the PI3K $\delta^{\mathrm{D} 910 \mathrm{~A}} \mathrm{~B}$ cell supernatant is primarily due to lower IL-10 concentrations. Moreover, as secreted IL-10 also affects B cells [45], we blocked IL-10 receptor on B cells to observe autocrine effect of IL-10. Interestingly, IL-10R blockade significantly increased IL-12p40 secretion in a dose-dependent manner in CpG-stimulated B cells (Figure S5). This finding indicates that low levels of IL-10 secretion from PI3K $\delta^{\text {D910A }}$ B cells influence not only other surrounding cells but also the B cell responsiveness to bacterial stimuli. PI3K $\delta$ signaling appears to modulate B cell phenotype both directly (by regulating TLR signaling) and indirectly (through an IL-10 autocrine pathway). 


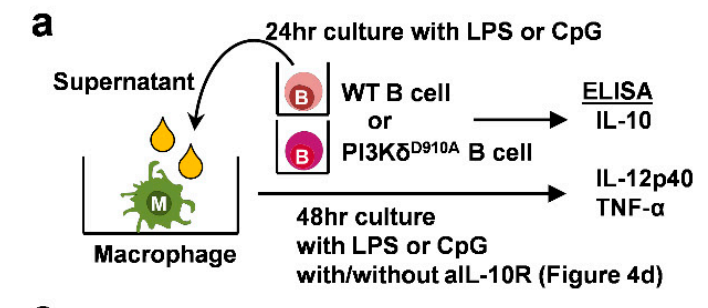

C

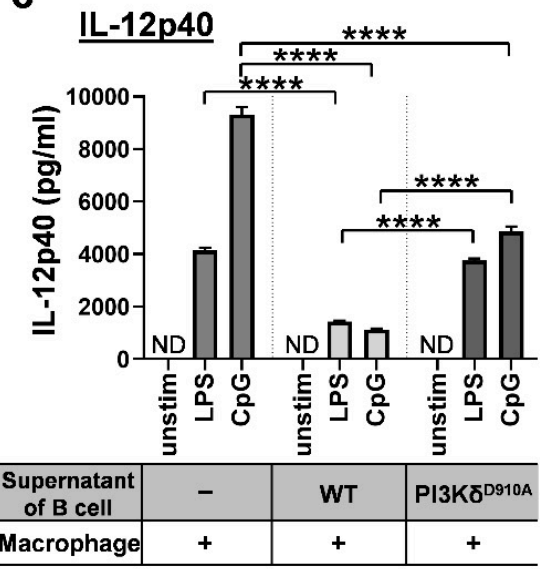

b

IL-10 concentration (pg/ml \pm SD)
\begin{tabular}{|c|c|c|}
\hline Stimuli & WT & Pl3K $\delta^{0910 A}$ \\
\hline LPS & $45.4 \pm 2.1$ & $2.5 \pm 0.9$ \\
\hline CpG & $287.8 \pm 14.6$ & $40.0 \pm 1.1$ \\
\hline
\end{tabular}

Figure 4. Secreted IL-10 from PI3K $\delta^{\mathrm{D} 910 \mathrm{~A}}$ B cells is not sufficient to regulate inflammatory cytokine production by macrophages in response to bacterial products. (a) $1 \times 10^{6}$ splenic B cells from WT or PI3K $\delta^{\text {D910A }}$ mice were cultured with LPS $(200 \mathrm{ng} / \mathrm{mL})$ or CpG $(500 \mathrm{nM})$ for $24 \mathrm{~h}$, then supernatants were harvested by spinning the culture cells down. (b) Concentrations of IL-10 in the supernatants were assessed by ELISA. The supernatants were added to $1 \times 10^{5}$ bone marrow derived macrophage (BMDM) cultures with the same concentration of LPS or CpG for another $48 \mathrm{~h}$. BMDM were derived from WT C57BL/6 mice. (c) The final supernatants were assessed for IL-12p40 and TNF- $\alpha$ by ELISA. (d) BMDMs were cultured in LPS (200 ng/mL)-containing supernatants from either WT B cells or PI3K $\delta^{\text {D910A }}$ B cells with anti-IL-10R $(0.1$ or $1 \mathrm{ng} / \mathrm{mL})$ or isotype IgG control $(1 \mathrm{ng} / \mathrm{mL})$ for $24 \mathrm{~h}$. IL-12p40 level was assessed by ELISA. Mean \pm SEM. Dunn's multiple comparisons test following ANOVA was used for $\mathbf{c}, \mathbf{d} .{ }^{*} p<0.05,{ }^{* * *} p<0.001,{ }^{* * * *} p<0.0001$. ND indicates not detected.

\subsection{PI3Kס-Signaling in B Cells Regulates Bacterial-Induced Pro-Inflammatory Cytokine Secretion by T Cells}

As effector $\mathrm{CD}^{+} \mathrm{T}$ cells play a critical role in the pathogenesis of IBD [1,3,4], we explored the interactions between $\mathrm{CD} 4^{+} \mathrm{T}$ cells and $\mathrm{B}$ cells in intestinal inflammation. WT naïve $\mathrm{CD} 4^{+} \mathrm{T}$ cells plus $I l 10^{-/-}$antigen presenting cells (APC) were co-cultured with $\mathrm{WT}, I l 10^{-/-}$, or PI3K $\delta^{\mathrm{D} 910 \mathrm{~A}} \mathrm{~B}$ cells in the presence of CBL (Figure 5a). CBL activated naïve T cells to produce inflammatory IFN- $\gamma$ and IL-17a in the presence of APC, while WT B cells [36], but not PI3K $\delta^{\text {D910A }}$ B cells, produced abundant IL-10 and decreased T cell inflammatory cytokines (Figure $5 b$ ). Furthermore, WT B cells significantly suppressed naïve $\mathrm{CD} 4^{+} \mathrm{T}$ cell proliferation, while either PI3K $\delta^{\mathrm{D} 910 \mathrm{~A}} \mathrm{~B}$ cells or WT B cells plus PI3K $\delta$-inhibitors negated the suppressive effect of WT B cells on T cells (Figure $5 c-e$ ). These results indicate that B cells regulate $\mathrm{CD} 4^{+}$T cell proliferation and production of IFN- $\gamma$ and IL-17 in response to bacteria and that $\mathrm{PI} 3 \mathrm{~K} \delta$ is required for these regulatory effects of $\mathrm{B}$ cells. 

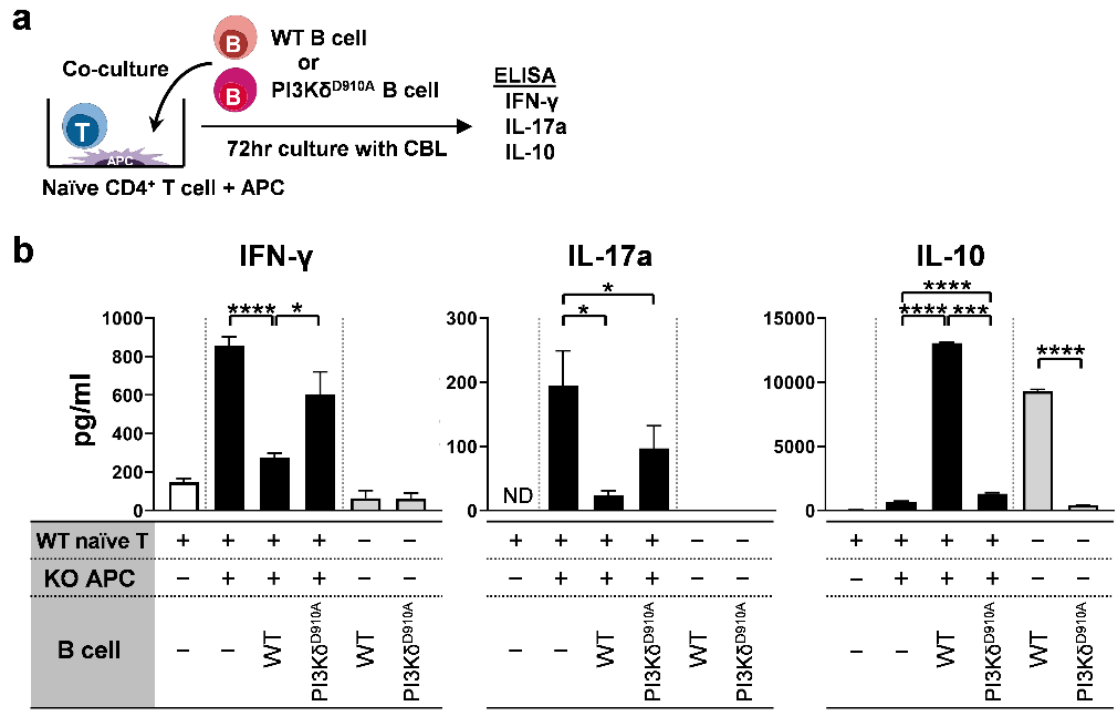

C

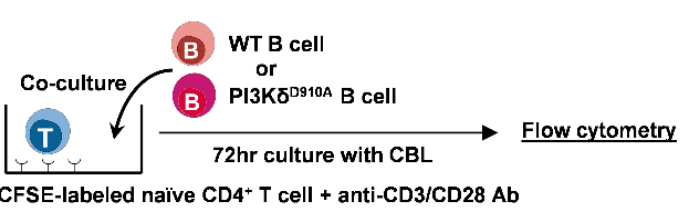

d Live CD4+ $\mathrm{T}$ cells
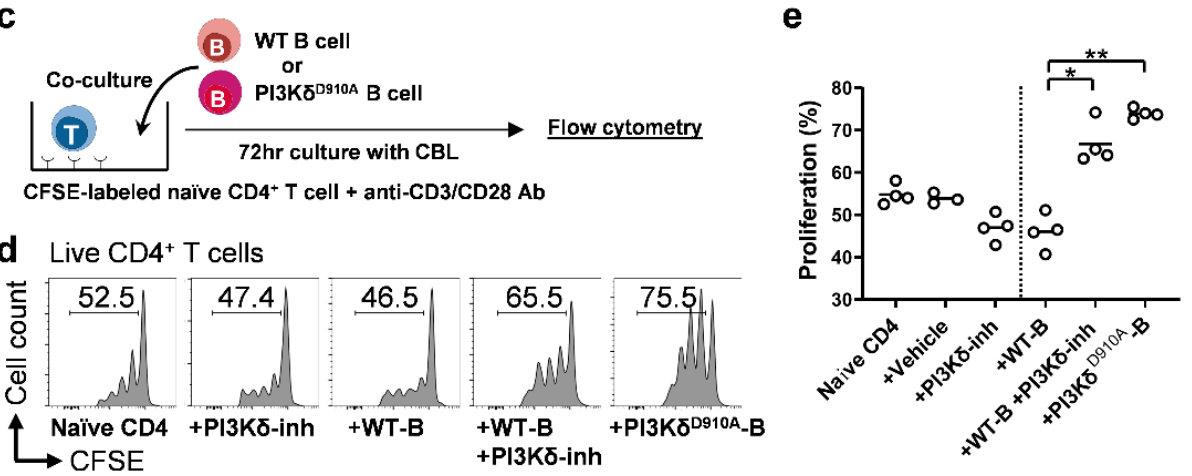

Figure 5. PI3K $\delta$-signaling in B cells regulates bacteria-stimulated inflammatory cytokine production by

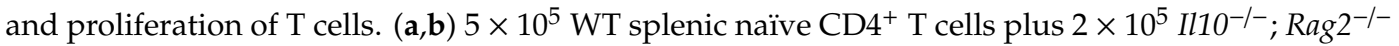
antigen-presenting cells (APC) were co-cultured with or without $1 \times 10^{6}$ splenic B cells in the presence of $10 \mu \mathrm{g} / \mathrm{mL}$ CBL for $72 \mathrm{~h}$. Supernatant levels of IL-10, IFN- $\gamma$ and IL-17a were measured by ELISA in duplicates. $\mathrm{N}=4-6 /$ group. (c-e) The $5 \times 10^{5}$ CFSE-labeled WT naïve CD4 ${ }^{+} \mathrm{T}$ cells were cultured with $1 \times 10^{6}$ B cells from WT or PI3K $\delta^{\text {D910A }}$ mice for $72 \mathrm{~h}$ with CBL $(10 \mu \mathrm{g} / \mathrm{mL})$. After culturing, single cells were stained and proliferation of naïve $\mathrm{CD} 4^{+} \mathrm{T}$ cells were assessed by flow cytometry. Representative histograms of live $\mathrm{CD} 4^{+} \mathrm{T}$ cells (Live/Dead ${ }^{\text {neg }} \mathrm{CD} 45^{+} \mathrm{TCR} \beta^{+} \mathrm{CD} 3^{+} \mathrm{CD} 4^{+} \mathrm{CD} 8^{\text {neg }}$ ) are shown in $\mathbf{d}$. Percentage of proliferating cells was demonstrated in e. Bars indicate the mean. Dunn's multiple comparisons test following one-way ANOVA was used for b,e. ${ }^{*} p<0.05,{ }^{* *} p<0.01,{ }^{* * *} p<$ $0.001{ }^{* * * *} p<0.0001$. ND indicates not detected.

\subsection{PI3KX-Signaling in B Cells is Required to Confer Protection Against T Cell-Mediated Colitis}

Given the fact that the PI3K $\delta$ pathway is involved in IL-10-mediated immune suppression by $B$ cells in vitro, we investigated the involvement of B cell PI3K $\delta$ in T cell-mediated colitis in vivo (Figure 6a). WT B cells decreased histologic inflammation in a $\mathrm{CD}^{+}$and $\mathrm{B}$ cell co-transfer colitis model with significantly less protection by either PI3K $\delta^{\mathrm{D} 910 \mathrm{~A}}$ or $I l 10^{-/-} \mathrm{B}$ cells (Figure $6 \mathrm{~b}, \mathrm{c}$ ). These results were confirmed by decreased levels of fecal Lcn (Figure 6d). Expression of colonic inflammatory cytokine genes, Il12b, Ifng, Il17 $a$ and Tnfa were significantly ameliorated by WT B cells but less-so by PI3K $\delta^{\mathrm{D} 910 \mathrm{~A}}$ and $I l 10^{-/-}$B cells (Figure 6e). Together, these in vivo results indicate that PI3K $\delta$ signaling plays a pivotal role in IL-10-producing B cell protection in T cell-mediated colitis. 


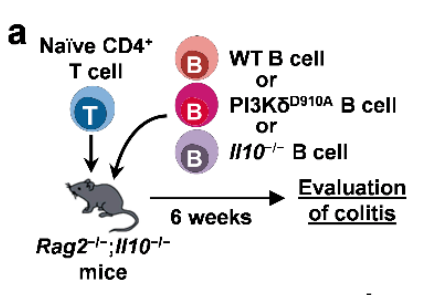

C

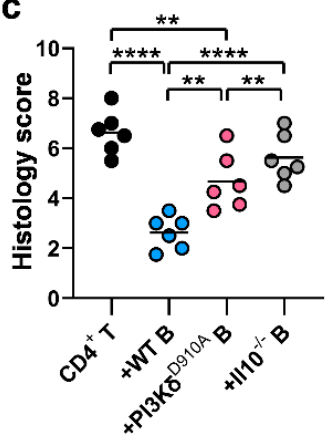

b

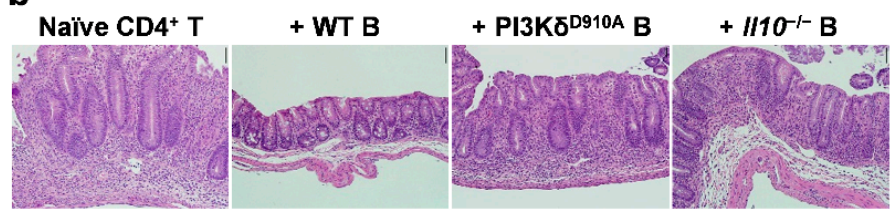

d

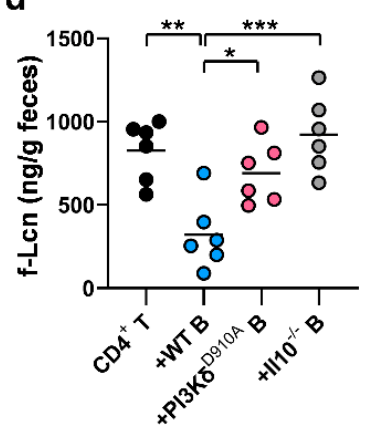

e

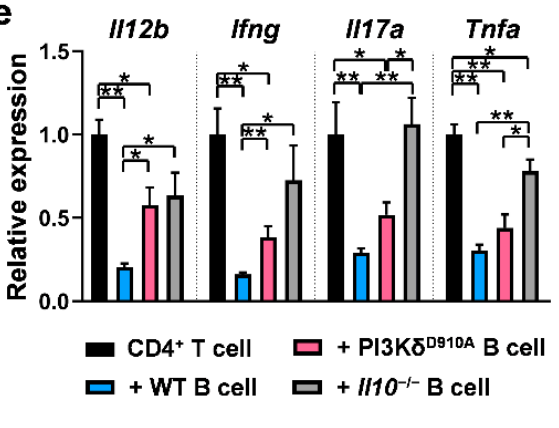

Figure 6. PI3K $\delta$-signaling in B cells is required to confer protection against $\mathrm{T}$ cell-mediated colitis. (a) $5 \times 10^{5}$ splenic naïve $\mathrm{CD} 4^{+} \mathrm{T}$ cells were co-transferred intraperitoneally with or without $1 \times 10^{6}$ splenic B cells from WT, PI3K $\delta^{\mathrm{D} 910 \mathrm{~A}}$, or $I l 10^{-/-}$mice into $\mathrm{Rag} 2^{-/-} ; \mathrm{Il10^{-/- }}$ mice. The severity of colitis was evaluated 6 weeks after cell transfer. $N=6 /$ group. (b) Representative images of H\&E-stained cecum are shown. Scale bar represents $100 \mu \mathrm{m}$. (c) Histology scores are shown. Bar indicates the mean. (d) Lipocalin-2 in fecal supernatant (f-Lcn) was assessed by ELISA. Bar indicates the mean. (e) Expression of inflammatory cytokines in the distal colon was assessed by qPCR. Relative quantification was normalized to WT expression levels. Dunn's multiple comparisons test following one-way ANOVA was used. ${ }^{*} p<0.05,{ }^{* *} p<0.01,{ }^{* * *} p<0.001,{ }^{* * * *} p<0.0001$.

\section{Discussion}

The present study demonstrates that a lack of PI3K $\delta$ signaling decreases bacteria-stimulated IL-10 secretion by B cells and impairs B cell function to inhibit inflammatory responses in macrophages and $\mathrm{T}$ cells. Adoptively transferred PI3K $\delta^{\mathrm{D} 910 \mathrm{~A}} \mathrm{~B}$ cells were unable to attenuate $\mathrm{T}$ cell-mediated colitis. These findings indicate that PI $3 \mathrm{~K} \delta$ signaling is a key protective pathway for mucosal homeostasis and prevention of intestinal inflammation through bacterial-activated IL-10-producing B cells.

Dysfunction of the PI3K $\delta$ pathway in mice leads to spontaneous colitis in the presence of resident bacteria and exacerbates mucosal inflammation in murine experimental colitis models [12,30-32]. In humans, the PI3K $\delta$ gene (PIK3CD) maps to the IBD7 susceptibility locus on chromosome 1p36 [28,29], while the PI3K $\delta$-inhibitor Idelalisib, a therapeutic agent for certain tumors, can cause colitis as a side effect [48]. Based on our present results showing that B cell PI3K $\delta$ plays an anti-inflammatory role in the activation of macrophages and $\mathrm{T}$ cells and can attenuate $\mathrm{T}$ cell-mediated colitis, these clinical and basic observations might be in part due to $\mathrm{PI} 3 \mathrm{~K} \delta$-mediated dysfunction of IL-10-producing regulatory $B$ cells. Despite previous evidence showing dysfunction of multiple types of innate immune cells in PI3K $\delta^{\mathrm{D} 910 \mathrm{~A}}$ mice $[12,32]$, the present study showed that defective PI3K $\delta$ signaling decreased the frequency and function of regulatory B cells in response to bacterial products to a greater extent than that of regulatory $\mathrm{T}$ cells or macrophages. Blockade of PI3K $\delta$ signaling caused B cells to lose their ability to control bacterial-activated inflammatory cytokine production by macrophages or $\mathrm{T}$ cells. Finally, intact B cell-specific PI3K $\delta$ signaling was sufficient to significantly ameliorate colitis in a T cell-transfer colitis model. These findings indicate that PI $3 \mathrm{~K} \delta$ signaling in B cells is a key determinant of the homeostatic phenotype of the mucosal immune system, and suggests that restoring or stimulating the PI3K $\delta$ pathway in B cells might be a therapeutic target in IBD.

Importantly, others have demonstrated contradictory roles for PI3K $\delta$ in inflammatory diseases outside the intestine. Blockade of PI3K $\delta$ attenuates inflammation in arthritis in $\mathrm{K} / \mathrm{BxN}$ serum-transferred mice [49], IgE- or ovalbumin-related allergic models [50-53], a multiple sclerosis model [54], 
imiquimod-induced dermatitis [55], and experimental systemic lupus erythematosus in BXSB mice [56]. Inhibition of PI3K $\delta$ signaling may predominantly suppress aggressive inflammatory immune cells over regulatory immune cells in non-IBD models, where resident intestinal bacteria are not the dominant activators of inflammation. Supporting this concept, pathogenic function of effector cells, such as neutrophils [49,51], CD8 ${ }^{+} \mathrm{T}$ cells [50,51], mast cells [50,51,53], Th2 cells [50-52], CD44 ${ }^{\text {high }}$ CD62L ${ }^{\text {low }} \mathrm{CD} 4{ }^{+}$T cells [54], Th17 cells [54-56], and autoreactive immunoglobulin-secreting B cells [56], were decreased by PI3K $\delta$ signaling blockade in experimental inflammation outside the intestine. In contrast, aberrant activation of innate immune cells (macrophages, dendritic and antigen-presenting cells) and Th1/Th17 cells, in concert with decreased regulatory cells (regulatory $\mathrm{T}$ cells and $\mathrm{B}$ cells and intestinal dysbiosis), strongly contribute to the onset and progression of IBD and experimental intestinal inflammation [2,3,5,6,9-11,14,17,45-47]. Interestingly, human regulatory $\mathrm{T}$ cells, compared to $\mathrm{CD}^{+}$or $\mathrm{CD} 8^{+} \mathrm{T}$ cells, were shown to be exquisitely sensitive to the effects of specific PI3K $\delta$ inhibition in terms of proliferation and suppressive function [57]. Another newly described immune deficiency/inflammatory condition termed activated PI3K $\delta$ syndrome (APDS) has emerged and contributed additional insight into the immunoregulatory role of PI3K $\delta$ in human diseases [58]. Patients with APDS have a gain of function mutation in the gene encoding PI3K $\delta$ (PIK3CD) and present with recurrent bacterial and herpesvirus sinopulmonary infections, lymphadenopathy, and autoimmune/inflammatory manifestations. It is tempting to speculate that patients with APDS demonstrate opposing immune phenotypes to that of patients with IBD, due to suppression of normal bactericidal/antiviral immune responses at mucosal surfaces. Ultimately, whether through inadequate pathogen clearance (in APDS) or prolonged inappropriate inflammatory response (in IBD), these two conditions both lead to aberrant chronic inflammation and its sequelae. These data suggest that defective PI3K $\delta$ signaling in response to resident bacteria might influence regulatory immune cells to a greater degree than effector immune cells in the intestine and other mucosal surfaces regularly in contact with resident microbes.

We also emphasize the importance of colonic lamina propria (cLP) IL-10-producing cells in intestinal homeostasis. cLP cells demonstrated markedly higher production of IL-10 and regulatory activity (IL-10/IL-12p40 ratio) compared with MLN and spleen cells in response to bacterial stimulation. The colon is an unique environment where constant exposure to resident bacteria and their products requires dedicated regulation via IL-10 to maintain homeostasis. Likewise, the colon may be more sensitive to defective IL-10 signaling compared with other organs. Our data showed that dysregulated immunity in PI3K $\delta^{\mathrm{D} 910 \mathrm{~A}}$ mice predominantly develops in the colon through diminished IL-10 production. PI3K $\delta^{\mathrm{D} 910 \mathrm{~A}}$ mice develop colitis characterized by microbiota-dependent Th1/Th17 cell expansion [12,31,32] despite low IFN- $\gamma$ production by antigen-stimulated PI3K $\delta^{\mathrm{D} 910 \mathrm{~A}} \mathrm{~T}$ cells [59]. This discrepancy remains unclear, but our co-culture assays revealed that defective PI3K $\delta$ signaling in B cells promoted low IL-10 and high IL-12p40 production, impaired suppression of IL-12p40 secretion by bacteria-stimulated macrophages, and promoted naïve T cell proliferation. Since IL-12p40 promotes differentiation of naïve T cells into Th1/Th17 cells [24,60], prolonged APC stimulation conditions (high IL-12p40 and low IL-10) by PI3K $\delta^{\text {D910A }}$ B cells may promote expansion of Th1/Th17 cells. Moreover, IL-12p40 and the Th1 cytokine IFN- $\gamma$ normally induce anti-inflammatory cytokines from T cells and B cells and regulatory cells as a negative feedback [40,45,61-63], but IL-10-producing regulatory B cells are not appropriately induced to make IL-10 in PI3K $\delta^{\mathrm{D} 910 \mathrm{~A}}$ mice (age older than 14 weeks). These findings indicate that homeostatic IL-10-production by B cells and IL-10 ${ }^{+}$regulatory $B$ cell numbers are not adequately induced under excessive inflammatory conditions in the absence of PI3K $\delta$ signaling, which likely worsens mucosal inflammation. Together, a deregulated immune phenotype (low IL-10 and high IL-12p40) of PI3K $\delta^{\text {D910A }} \mathrm{B}$ cells appears to contribute to the pathogenesis of $\mathrm{T}$ cell-mediated colitis.

One of the limitations of the present study is that we did not assess IL-10-independent regulatory factors of PI3K $\delta$ B cells, which include TGF- $\beta$, IL-27, IL-35, IgA and induction of regulatory T cells $[6,9-11,45-47,64]$. However, our in vitro assays with an anti-IL-10 receptor antibody demonstrate 
the importance of IL-10 produced by B cells in regulating inflammatory cytokines from macrophages, $\mathrm{T}$ cells, and B cells themselves. Given that deficiency of IL-10, PI3K $\delta$, or luminal IgA affects gut microbiota colonization [65-67], profiling enteric microbiota in PI3K $\delta^{\mathrm{D} 910 \mathrm{~A}}$ mice may unveil a mutual relationship between PI3K $\delta$ function in B cells and microbial dysbiosis in IBD. An additional limitation is that we were unable to determine which bacterial species, groups or components are responsible for stimulating IL-10 through PI3K $\delta$ in the murine B cells with our cecal lysates. This can be addressed in future studies by exploring the relative efficacy of lysates of relevant individual resident intestinal bacterial species or their components. Finally, future studies should test the ability of human fecal samples to activate PI3K $\delta$-dependent protective functions in human-derived colonic immune cells.

In conclusion, our study provides evidence that genetic dysfunction or pharmacological blockade of PI3K $\delta$ in B cells lead to globally dysfunctional homeostatic pathways in the intestine and consequent development of intestinal inflammation. As PI3K signaling affects several key immune pathways, investigating cell-specific, site-specific and disease-specific PI3K-related signaling is important for better understanding of the pathogenesis of IBD and regulation of mucosal homeostasis. This knowledge may contribute to the development of novel and safe pharmacological therapies in IBD.

Supplementary Materials: The following are available online at http:/www.mdpi.com/2073-4409/8/10/1121/s1, Figure S1: B cell population is significantly reduced in PI3K $\delta$ D910A mice, Figure S2: The inflammatory or regulatory phenotypes of MLN and spleen cells are determined by PI3K $\delta$ signaling, Figure S3: The median fluorescence intensities of GFP in T cells and B cells, Figure S4: Phenotypic characteristics of B cells in PI3K $\delta^{\mathrm{D} 910 \mathrm{~A}}$ mice, Figure S5: Blockade of IL-10 signaling increases IL-12p40 secretion by B cells, Table S1: Antibodies used in the present study.

Author Contributions: Conceptualization, A.O., Y.M. and R.B.S.; Funding acquisition, R.B.S.; Investigation, A.O., Y.M. and B.L.; Methodology, A.O., Y.M., B.L., J.W.H., E.C.S. and T.K.; Resources, E.C.S., T.K. and S.E.P.; Supervision, R.B.S.; Writing—original draft, A.O. and Y.M.; Writing—review and editing, J.W.H., E.C.S., T.K., S.E.P. and R.B.S.

Funding: This research was funded by National Institute of Health, R01DK53347, P01DK094779 and P30DK34987.

Acknowledgments: We thank B. Vanhaesebroeck for providing PI3Kp1108D910A/D910A mice and C.L. Karp for providing Il10 ${ }^{\mathrm{eGFP}}$ reporter mice.

Conflicts of Interest: The authors declare no conflict of interest.

\section{References}

1. Liu, J.Z.; van Sommeren, S.; Huang, H.; Ng, S.C.; Alberts, R.; Takahashi, A.; Ripke, S.; Lee, J.C.; Jostins, L.; Shah, T.; et al. Association analyses identify 38 susceptibility loci for inflammatory bowel disease and highlight shared genetic risk across populations. Nat. Genet. 2015, 47, 979-986. [CrossRef] [PubMed]

2. Sartor, R.B.; Wu, G.D. Roles for Intestinal Bacteria, Viruses, and Fungi in Pathogenesis of Inflammatory Bowel Diseases and Therapeutic Approaches. Gastroenterology 2017, 152, 327-339.e4. [CrossRef] [PubMed]

3. Friedrich, M.; Pohin, M.; Powrie, F. Cytokine Networks in the Pathophysiology of Inflammatory Bowel Disease. Immunity 2019, 50, 992-1006. [CrossRef] [PubMed]

4. Chen, L.; Wilson, J.E.; Koenigsknecht, M.J.; Chou, W.-C.; Montgomery, S.A.; Truax, A.D.; June Brickey, W.; Packey, C.D.; Maharshak, N.; Matsushima, G.K.; et al. NLRP12 attenuates colon inflammation by maintaining colonic microbial diversity and promoting protective commensal bacterial growth. Nat. Immunol. 2017, $18,1-14$.

5. Atarashi, K.; Honda, K. Microbiota in autoimmunity and tolerance. Curr. Opin. Immunol. 2011, 23, 761-768. [CrossRef] [PubMed]

6. Mishima, Y.; Oka, A.; Liu, B.; Herzog, J.W.; Eun, C.S.; Fan, T.-J.; Bulik-Sullivan, E.; Carroll, I.M.; Hansen, J.J.; Chen, L.; et al. Microbiota maintain colonic homeostasis by activating TLR2/MyD88/PI3K signaling in IL-10-producing regulatory B cells. J. Clin. Investig. 2019, 129, 130. [CrossRef] [PubMed]

7. Ivanov, I.I.; Littman, D.R. Modulation of immune homeostasis by commensal bacteria. Curr. Opin. Microbiol. 2011, 14, 106-114. [CrossRef]

8. Makita, S.; Kanai, T.; Oshima, S.; Uraushihara, K.; Totsuka, T.; Sawada, T.; Nakamura, T.; Koganei, K.; Fukushima, T.; Watanabe, M. CD4+CD25bright T cells in human intestinal lamina propria as regulatory cells. J. Immunol. 2004, 173, 3119-3130. [CrossRef] 
9. Mishima, Y.; Ishihara, S.; Aziz, M.M.; Oka, A.; Kusunoki, R.; Otani, A.; Tada, Y.; Li, Y.Y.; Moriyama, I.; Oshima, N.; et al. Decreased production of interleukin-10 and transforming growth factor- $\beta$ in Toll-like receptor-activated intestinal B cells in SAMP1/Yit mice. Immunology 2010, 131, 473-487. [CrossRef]

10. Oka, A.; Ishihara, S.; Mishima, Y.; Tada, Y.; Kusunoki, R.; Fukuba, N.; Yuki, T.; Kawashima, K.; Matsumoto, S.; Kinoshita, Y. Role of Regulatory B Cells in Chronic Intestinal Inflammation: Association with Pathogenesis of Crohn's Disease. Inflamm. Bowel Dis. 2014, 20, 315-328. [CrossRef]

11. Mishima, Y.; Liu, B.; Hansen, J.J.; Sartor, R.B. Resident bacteria-stimulated IL-10-secreting B cells ameliorate T cell-mediated colitis by inducing Tr-1 cells that require IL-27-signaling. Cell. Mol. Gastroenterol. Hepatol. 2015, 1, 295-310. [CrossRef] [PubMed]

12. Uno, J.K.; Rao, K.N.; Matsuoka, K.; Sheikh, S.Z.; Kobayashi, T.; Li, F.; Steinbach, E.C.; Sepulveda, A.R.; Vanhaesebroeck, B.; Sartor, R.B.; et al. Altered macrophage function contributes to colitis in mice defective in the phosphoinositide-3 kinase subunit p1108. Gastroenterology 2010, 139, 1642-1653.e6. [CrossRef] [PubMed]

13. Fuchs, E.J.; Matzinger, P. B cells turn off virgin but not memory T cells. Science 1992, 258, 1156-1159. [CrossRef] [PubMed]

14. Mizoguchi, A.; Mizoguchi, E.; Takedatsu, H.; Blumberg, R.S.; Bhan, A.K. Chronic intestinal inflammatory condition generates IL-10-producing regulatory B cell subset characterized by CD1d upregulation. Immunity 2002, 16, 219-230. [CrossRef]

15. El Fassi, D.; Nielsen, C.H.; Kjeldsen, J.; Clemmensen, O.; Hegedüs, L. Ulcerative colitis following B lymphocyte depletion with rituximab in a patient with Graves' disease. Gut 2008, 57, 714-715. [CrossRef] [PubMed]

16. Goetz, M.; Atreya, R.; Ghalibafian, M.; Galle, P.R.; Neurath, M.F. Exacerbation of ulcerative colitis after rituximab salvage therapy. Inflamm. Bowel Dis. 2007, 13, 1365-1368. [CrossRef] [PubMed]

17. Yanaba, K.; Yoshizaki, A.; Asano, Y.; Kadono, T.; Tedder, T.F.; Sato, S. IL-10-producing regulatory B10 cells inhibit intestinal injury in a mouse model. Am. J. Pathol. 2011, 178, 735-743. [CrossRef]

18. Matsushita, T.; Le Huu, D.; Kobayashi, T.; Hamaguchi, Y.; Hasegawa, M.; Naka, K.; Hirao, A.; Muramatsu, M.; Takehara, K.; Fujimoto, M. A novel splenic B1 regulatory cell subset suppresses allergic disease through phosphatidylinositol 3-kinase-Akt pathway activation. J. Allergy Clin. Immunol. 2016, 138, 1170-1182.e9. [CrossRef]

19. Kok, K.; Geering, B.; Vanhaesebroeck, B. Regulation of phosphoinositide 3-kinase expression in health and disease. Trends Biochem. Sci. 2009, 34, 115-127. [CrossRef]

20. Kuo, C.-C.; Lin, W.-T.; Liang, C.-M.; Liang, S.-M. Class I and III phosphatidylinositol 3'-kinase play distinct roles in TLR signaling pathway. J. Immunol. 2006, 176, 5943-5949. [CrossRef]

21. Fukao, T.; Koyasu, S. PI3K and negative regulation of TLR signaling. Trends Immunol. 2003, 24, 358-363. [CrossRef]

22. Liew, F.Y.; Xu, D.; Brint, E.K.; O’Neill, L.A.J. Negative regulation of toll-like receptor-mediated immune responses. Nat. Rev. Immunol. 2005, 5, 446-458. [CrossRef] [PubMed]

23. Cahill, C.M.; Rogers, J.T.; Walker, W.A. The role of phosphoinositide 3-kinase signaling in intestinal inflammation. J. Signal Transduct. 2012, 2012, 358476. [CrossRef] [PubMed]

24. Fukao, T.; Tanabe, M.; Terauchi, Y.; Ota, T.; Matsuda, S.; Asano, T.; Kadowaki, T.; Takeuchi, T.; Koyasu, S. PI3K-mediated negative feedback regulation of IL-12 production in DCs. Nat. Immunol. 2002, 3, 875-881. [CrossRef] [PubMed]

25. Martin, M.; Schifferle, R.E.; Cuesta, N.; Vogel, S.N.; Katz, J.; Michalek, S.M. Role of the phosphatidylinositol 3 kinase-Akt pathway in the regulation of IL-10 and IL-12 by Porphyromonas gingivalis lipopolysaccharide. J. Immunol. 2003, 171, 717-725. [CrossRef] [PubMed]

26. Wang, H.; Garcia, C.A.; Rehani, K.; Cekic, C.; Alard, P.; Kinane, D.F.; Mitchell, T.; Martin, M. IFN-beta production by TLR4-stimulated innate immune cells is negatively regulated by GSK3-beta. J. Immunol. 2008, 181, 6797-6802. [CrossRef] [PubMed]

27. Vanhaesebroeck, B.; Welham, M.J.; Kotani, K.; Stein, R.; Warne, P.H.; Zvelebil, M.J.; Higashi, K.; Volinia, S.; Downward, J.; Waterfield, M.D. P110delta, a novel phosphoinositide 3-kinase in leukocytes. Proc. Natl. Acad. Sci. USA 1997, 94, 4330-4335. [CrossRef]

28. Seki, N.; Nimura, Y.; Ohira, M.; Saito, T.; Ichimiya, S.; Nomura, N.; Nakagawara, A. Identification and chromosome assignment of a human gene encoding a novel phosphatidylinositol-3 kinase. DNA Res. 1997, 4, 355-358. [CrossRef] 
29. Cho, J.H.; Nicolae, D.L.; Ramos, R.; Fields, C.T.; Rabenau, K.; Corradino, S.; Brant, S.R.; Espinosa, R.; LeBeau, M.; Hanauer, S.B.; et al. Linkage and linkage disequilibrium in chromosome band 1p36 in American Chaldeans with inflammatory bowel disease. Hum. Mol. Genet. 2000, 9, 1425-1432. [CrossRef]

30. Conley, M.E.; Dobbs, A.K.; Quintana, A.M.; Bosompem, A.; Wang, Y.-D.; Coustan-Smith, E.; Smith, A.M.; Perez, E.E.; Murray, P.J. Agammaglobulinemia and absent B lineage cells in a patient lacking the p $85 \alpha$ subunit of PI3K. J. Exp. Med. 2012, 209, 463-470. [CrossRef]

31. Okkenhaug, K.; Bilancio, A.; Farjot, G.; Priddle, H.; Sancho, S.; Peskett, E.; Pearce, W.; Meek, S.E.; Salpekar, A.; Waterfield, M.D.; et al. Impaired B and T cell antigen receptor signaling in p110delta PI 3-kinase mutant mice. Science 2002, 297, 1031-1034. [CrossRef] [PubMed]

32. Steinbach, E.C.; Kobayashi, T.; Russo, S.M.; Sheikh, S.Z.; Gipson, G.R.; Kennedy, S.T.; Uno, J.K.; Mishima, Y.; Borst, L.B.; Liu, B.; et al. Innate PI3K p110 regulates Th1/Th17 development and microbiota-dependent colitis. J. Immunol. 2014, 192, 3958-3968. [CrossRef] [PubMed]

33. Patton, D.T.; Garden, O.A.; Pearce, W.P.; Clough, L.E.; Monk, C.R.; Leung, E.; Rowan, W.C.; Sancho, S.; Walker, L.S.K.; Vanhaesebroeck, B.; et al. Cutting edge: The phosphoinositide 3-kinase p110 delta is critical for the function of CD4+CD25+Foxp3+ regulatory T cells. J. Immunol. 2006, 177, 6598-6602. [CrossRef] [PubMed]

34. Madan, R.; Demircik, F.; Surianarayanan, S.; Allen, J.L.; Divanovic, S.; Trompette, A.; Yogev, N.; Gu, Y.; Khodoun, M.; Hildeman, D.; et al. Nonredundant roles for B cell-derived IL-10 in immune counter-regulation. J. Immunol. 2009, 183, 2312-2320. [CrossRef] [PubMed]

35. Kim, S.C.; Tonkonogy, S.L.; Albright, C.A.; Tsang, J.; Balish, E.J.; Braun, J.; Huycke, M.M.; Sartor, R.B. Variable phenotypes of enterocolitis in interleukin 10-deficient mice monoassociated with two different commensal bacteria. Gastroenterology 2005, 128, 891-906. [CrossRef] [PubMed]

36. Liu, B.; Tonkonogy, S.L.; Sartor, R.B. Antigen-presenting cell production of IL-10 inhibits T-helper 1 and 17 cell responses and suppresses colitis in mice. Gastroenterology 2011, 141, 653-662.e4. [CrossRef] [PubMed]

37. Duncan, S.H.; Hold, G.L.; Harmsen, H.J.M.; Stewart, C.S.; Flint, H.J. Growth requirements and fermentation products of Fusobacterium prausnitzii, and a proposal to reclassify it as Faecalibacterium prausnitzii gen. nov., comb. nov. Int. J. Syst. Evol. Microbiol. 2002, 52, 2141-2146.

38. Chassaing, B.; Srinivasan, G.; Delgado, M.A.; Young, A.N.; Gewirtz, A.T.; Vijay-Kumar, M. Fecal lipocalin 2, a sensitive and broadly dynamic non-invasive biomarker for intestinal inflammation. PLoS ONE 2012, 7, e44328. [CrossRef]

39. Scapini, P.; Lamagna, C.; Hu, Y.; Lee, K.; Tang, Q.; DeFranco, A.L.; Lowell, C.A. B cell-derived IL-10 suppresses inflammatory disease in Lyn-deficient mice. Proc. Natl. Acad. Sci. USA 2011, 108, E823-E832. [CrossRef]

40. Noh, J.; Noh, G.; Lee, S.J.; Lee, J.H.; Kim, A.; Kim, H.S.; Choi, W.S. Tolerogenic effects of interferon-gamma with induction of allergen-specific interleukin-10-producing regulatory B cell (Br1) changes in non-IgE-mediated food allergy. Cell. Immunol. 2012, 273, 140-149. [CrossRef]

41. Van der Veeken, J.; Gonzalez, A.J.; Cho, H.; Arvey, A.; Hemmers, S.; Leslie, C.S.; Rudensky, A.Y. Memory of Inflammation in Regulatory T Cells. Cell 2016, 166, 977-990. [CrossRef] [PubMed]

42. Ramadani, F.; Bolland, D.J.; Garcon, F.; Emery, J.L.; Vanhaesebroeck, B.; Corcoran, A.E.; Okkenhaug, K. The PI3K isoforms p110alpha and p110delta are essential for pre-B cell receptor signaling and B cell development. Sci. Signal. 2010, 3, ra60. [CrossRef] [PubMed]

43. Sellon, R.K.; Tonkonogy, S.; Schultz, M.; Dieleman, L.A.; Grenther, W.; Balish, E.; Rennick, D.M.; Sartor, R.B. Resident enteric bacteria are necessary for development of spontaneous colitis and immune system activation in interleukin-10-deficient mice. Infect. Immun. 1998, 66, 5224-5231. [PubMed]

44. Hawkins, P.T.; Stephens, L.R. PI3K signalling in inflammation. Biochim. Biophys. Acta 2015, 1851, $882-897$. [CrossRef]

45. Mizoguchi, A.; Bhan, A.K. A case for regulatory B cells. J. Immunol. 2006, 176, 705-710. [CrossRef] [PubMed]

46. Tedder, T.F. B10 Cells: A Functionally Defined Regulatory B Cell Subset. J. Immunol. 2015, 194, $1395-1401$. [CrossRef] [PubMed] 
47. Nishida, A.; Lau, C.W.; Mizoguchi, E.; Mizoguchi, A. Regulatory B cells in mouse models of intestinal inflammation. Methods Mol. Biol. 2014, 1190, 227-241. [PubMed]

48. Coutré, S.E.; Barrientos, J.C.; Brown, J.R.; de Vos, S.; Furman, R.R.; Keating, M.J.; Li, D.; O’Brien, S.M.; Pagel, J.M.; Poleski, M.H.; et al. Management of adverse events associated with idelalisib treatment: Expert panel opinion. Leuk. Lymphoma 2015, 56, 2779-2786. [CrossRef]

49. Randis, T.M.; Puri, K.D.; Zhou, H.; Diacovo, T.G. Role of PI3Kdelta and PI3Kgamma in inflammatory arthritis and tissue localization of neutrophils. Eur. J. Immunol. 2008, 38, 1215-1224. [CrossRef]

50. Lee, K.S.; Lee, H.K.; Hayflick, J.S.; Lee, Y.C.; Puri, K.D. Inhibition of phosphoinositide 3-kinase delta attenuates allergic airway inflammation and hyperresponsiveness in murine asthma model. FASEB J. 2006, 20, 455-465. [CrossRef]

51. Doukas, J.; Eide, L.; Stebbins, K.; Racanelli-Layton, A.; Dellamary, L.; Martin, M.; Dneprovskaia, E.; Noronha, G.; Soll, R.; Wrasidlo, W.; et al. Aerosolized phosphoinositide 3-kinase gamma/delta inhibitor TG100-115 [3-[2,4-diamino-6-(3-hydroxyphenyl)pteridin-7-yl]phenol] as a therapeutic candidate for asthma and chronic obstructive pulmonary disease. J. Pharmacol. Exp. Ther. 2009, 328, 758-765. [CrossRef] [PubMed]

52. Nashed, B.F.; Zhang, T.; Al-Alwan, M.; Srinivasan, G.; Halayko, A.J.; Okkenhaug, K.; Vanhaesebroeck, B.; Hayglass, K.T.; Marshall, A.J. Role of the phosphoinositide 3-kinase p110delta in generation of type 2 cytokine responses and allergic airway inflammation. Eur. J. Immunol. 2007, 37, 416-424. [CrossRef] [PubMed]

53. Ali, K.; Camps, M.; Pearce, W.P.; Ji, H.; Rückle, T.; Kuehn, N.; Pasquali, C.; Chabert, C.; Rommel, C.; Vanhaesebroeck, B. Isoform-specific functions of phosphoinositide 3-kinases: p110 delta but not p110 gamma promotes optimal allergic responses in vivo. J. Immunol. 2008, 180, 2538-2544. [CrossRef] [PubMed]

54. Haylock-Jacobs, S.; Comerford, I.; Bunting, M.; Kara, E.; Townley, S.; Klingler-Hoffmann, M.; Vanhaesebroeck, B.; Puri, K.D.; McColl, S.R. PI3K $\delta$ drives the pathogenesis of experimental autoimmune encephalomyelitis by inhibiting effector T cell apoptosis and promoting Th17 differentiation. J. Autoimmun. 2011, 36, 278-287. [CrossRef] [PubMed]

55. Roller, A.; Perino, A.; Dapavo, P.; Soro, E.; Okkenhaug, K.; Hirsch, E.; Ji, H. Blockade of phosphatidylinositol 3-kinase $\mathrm{PI} 3 \mathrm{~K} \delta$ or $\mathrm{PI} 3 \mathrm{~K} \gamma$ reduces IL-17 and ameliorates imiquimod-induced psoriasis-like dermatitis. J. Immunol. 2012, 189, 4612-4620. [CrossRef] [PubMed]

56. Wang, Y.; Zhang, L.; Wei, P.; Zhang, H.; Liu, C. Inhibition of PI3K $\delta$ improves systemic lupus in mice. Inflammation 2014, 37, 978-983. [CrossRef] [PubMed]

57. Chellappa, S.; Kushekhar, K.; Munthe, L.A.; Tjønnfjord, G.E.; Aandahl, E.M.; Okkenhaug, K.; Taskén, K. The PI3K p110 Isoform Inhibitor Idelalisib Preferentially Inhibits Human Regulatory T Cell Function. J. Immunol. 2019, 202, 1397-1405. [CrossRef]

58. Coulter, T.I.; Chandra, A.; Bacon, C.M.; Babar, J.; Curtis, J.; Screaton, N.; Goodlad, J.R.; Farmer, G.; Steele, C.L.; Leahy, T.R.; et al. Clinical spectrum and features of activated phosphoinositide 3-kinase $\delta$ syndrome: A large patient cohort study. J. Allergy Clin. Immunol. 2017, 139, 597-606.e4. [CrossRef]

59. Okkenhaug, K.; Patton, D.T.; Bilancio, A.; Garçon, F.; Rowan, W.C.; Vanhaesebroeck, B. The p110delta isoform of phosphoinositide 3-kinase controls clonal expansion and differentiation of Th cells. J. Immunol. 2006, 177, 5122-5128. [CrossRef]

60. Tait Wojno, E.D.; Hunter, C.A.; Stumhofer, J.S. The Immunobiology of the Interleukin-12 Family: Room for Discovery. Immunity 2019, 50, 851-870. [CrossRef]

61. Kucharzik, T.; Stoll, R.; Lügering, N.; Domschke, W. Circulating antiinflammatory cytokine IL-10 in patients with inflammatory bowel disease (IBD). Clin. Exp. Immunol. 1995, 100, 452-456. [CrossRef]

62. Cope, A.; Le Friec, G.; Cardone, J.; Kemper, C. The Th1 life cycle: Molecular control of IFN- $\gamma$ to IL-10 switching. Trends Immunol. 2011, 32, 278-286. [CrossRef] [PubMed]

63. Meyaard, L.; Hovenkamp, E.; Otto, S.A.; Miedema, F. IL-12-induced IL-10 production by human T cells as a negative feedback for IL-12-induced immune responses. J. Immunol. 1996, 156, 2776-2782. [PubMed]

64. Dambuza, I.M.; He, C.; Choi, J.K.; Yu, C.-R.; Wang, R.; Mattapallil, M.J.; Wingfield, P.T.; Caspi, R.R.; Egwuagu, C.E. IL-12p35 induces expansion of IL-10 and IL-35-expressing regulatory B cells and ameliorates autoimmune disease. Nat. Commun. 2017, 8, 719. [CrossRef] [PubMed] 
65. Fadlallah, J.; Kafsi, H.E.; Sterlin, D.; Juste, C.; Parizot, C.; Dorgham, K.; Autaa, G.; Gouas, D.; Almeida, M.; Lepage, P.; et al. Microbial ecology perturbation in human IgA deficiency. Sci. Transl. Med. 2018, 10, eaan1217. [CrossRef] [PubMed]

66. Madsen, K.L.; Doyle, J.S.; Jewell, L.D.; Tavernini, M.M.; Fedorak, R.N. Lactobacillus species prevents colitis in interleukin 10 gene-deficient mice. Gastroenterology 1999, 116, 1107-1114. [CrossRef]

67. Burnham, C.-A.D.; Shokoples, S.E.; Tyrrell, G.J. Invasion of HeLa cells by group B streptococcus requires the phosphoinositide-3-kinase signalling pathway and modulates phosphorylation of host-cell Akt and glycogen synthase kinase-3. Microbiology 2007, 153, 4240-4252. [CrossRef]

(C) 2019 by the authors. Licensee MDPI, Basel, Switzerland. This article is an open access article distributed under the terms and conditions of the Creative Commons Attribution (CC BY) license (http://creativecommons.org/licenses/by/4.0/). 